\title{
HÜKÜM UYUŞMAZLIĞINA BAŞVURU BİREYSEL BAŞVURU AÇISINDAN TÜKETILMESI GEREKEN BİR YOL MUDUR? (Anayasa Mahkemesi Kararı İncelemesi)
}

\author{
DOI: $10.21492 /$ inuhfd.388103
}

\section{Ufuk YEŞIL ${ }^{*}$}

\section{Özet}

2010 yılında yapılan Anayasa değişikliğiyle birlikte temel hak ve özgürlüklerinin kamu gücü kullanılarak ihlâl edildiğini düşünen kişilere, Anayasa Mahkemesine bireysel başvuruda bulunabilme hakkı tanınmıştır. Ancak bu hakkın kullanımı bazı şartların varlığına bağlıdır. Bu şartlardan birisi kanunlarda öngörülmüş olan idari ve yargısal başvuru yollarının tüketilmesidir. Farklı yargı kollarına mensup mahkemelerce verilen kararlar arasındaki çelişki nedeniyle hakkın yerine getirilemediği durumlarda ortaya çıkan hüküm uyuşmazlığının çözümü için Uyuşmazlık Mahkemesine başvuru da, bireysel başvuru açısından tüketilmesi gereken yargısal yollardan birisidir ve bu yola müracaat edilmeden yapılacak bireysel başvuru, başvuru yollarının tüketilmemesi nedeniyle reddedilecektir.

Anahtar Kelimeler: Anayasa Mahkemesi, Bireysel Başvuru, Uyuşmazlık Mahkemesi, Hüküm Uyuşmazlığı, Başvuru Yollarının Tüketilmesi

\section{WHETHER A REQUEST FOR CONFLICT OF JUDGMENTS IS A REMEDY TO EXHAUST IN TERMS OF INDIVIDUAL APPLICATION? (The Review of the Judgment of the Constitutional Court)}

\begin{abstract}
With the Constitutional amendments on 2010, every person may apply to the Constitutional Court alleging that the public power has violated any one of his/her fundamental rights and freedoms secured under the Constitution. However, the use of this right depends on the existence of certain conditions. One of these conditions is the exhaustion of all administrative and judicial remedies prescribed by law. The Conflict of Judgment between assigned courts that belongs to different jurisdictions is one of the compulsory judicial ways that should be consumed in terms of individual application before the Constitutional Court and this regards, without using this procedure of the individual application will be rejected for non-exhaustion of remedies.
\end{abstract}

Keywords: Constitutional Court, Individual Applications, the Court of Jurisdictional Disputes, Conflict of Judgment, Exhaustion of Domestic Remedies,

\footnotetext{
* Dr. Hakim, Uyuşmazlık Mahkemesi Genel Sekreteri, ufukyesil333@gmail.com.
} 


\section{Giriș}

Yarg1 ayrılığ1 (İdari rejim) sistemini benimseyen ülkemizde, bu sistemin bir sonucu olarak birden fazla yargı kolu faaliyet göstermektedir. Farklı yargı kollarına dahil mahkemelerin en az ikisi tarafindan aynı konu ve sebebe ilişkin farklı kararlar verilmesi ve bu kararların kesinleşerek icrai nitelik kazanması mümkündür. Kararın kesinleşmesinin ardından bu kararın uygulanmasını isteyen tarafın ilgili idari makamlara başvurusu hâlinde, aynı konuda iki ayrı mahkemece verilmiş ve kesinleşmiş kararlar bulunması ve kararlar arasında çelişki olması nedeniyle kararların hiçbirisi dava konusu olaya uygulanamamakta ve bu durum mağduriyetlere neden olmaktadır. Hak arama hürriyeti ile kanuni hâkim güvencesinin Anayasamızda düzenlenmiş olması ve hukuk devletinin bir gereği olarak kararlar arasındaki çelişkinin giderilip hakkın yerine getirilmesinin sağlanması için hüküm uyuşmazlığı müessesesi getirilmiş ve bu uyuşmazlığı çözme görevi 2247 sayılı Uyuşmazlık Mahkemesinin Kuruluş ve İşleyişi Hakkında Kanun ${ }^{1}$ (UMK) ile Uyuşmazlık Mahkemesi (UM)' ne verilmiştir².

Çalışmanın konusunu, bir bireysel başvuru dosyasında iddia edilen hak ihlâlleriyle ilgili hususların hüküm uyuşmazlığı kapsamında kalmasına rağmen, bu yola müracaat edilmeden Anayasa Mahkemesi'ne başvurulması üzerine Mahkeme'nin, başvuru yollarının tüketilmemesi nedeniyle başvurunun kabul edilemez olduğuna ilişkin kararının incelenmesi oluşturmaktadır. Çalışmada, hüküm uyuşmazlığının oluşma şartları ve çözüm usulü ile başvuru yollarının tüketilmemesi kavramı 1şığında Anayasa Mahkemesi kararının değerlendirilmesine yer verilmiştir.

\section{Hüküm Uyuşmazlığı ve Çözüm Usulü}

Hüküm uyuşmazlığı; UMK'nun 24 ve 25 . maddelerinde düzenlenmiş bir başvuru yolu olup, farklı yargı kollarına dâhil mahkemelerden en az ikisi tarafından verilip kesinleșen kararlar

${ }^{1} 22.6 .1979$ tarihli ve 16674 sayılı Resmi Gazete.

2 ONAR, Sıddık Sami, İdare Hukukunun Umumi Esasları, C. 1, 3. Bası, İsmail Akgün Matbaası, İstanbul, 1966, s. 1859; TERCAN, Erdal, "Hüküm Uyuşmazlığında Uyuşmazlık Mahkemesince Esas Hakkında Yeni Bir Karar Verilmesi”, Uyuşmazlık Mahkemesi Dergisi 70. Yıl Armağanı, S. 5, Ankara, 2015, s. 789-790, ("Esas Hakkında"); YEŞILL, Ufuk, Türk Yargı Sisteminde Görev ve Hüküm Uyuşmazlıklarının Çözüm Usulü, Uyuşmazlık Mahkemesi Yayınları, Ankara, 2016, s. 254-255. 
arasındaki çelişki nedeniyle hakkın yerine getirilmesinin imkânsız olması nedeniyle bu çelişkinin giderilmesinin UM'den istenilmesidir. Çalışmanın bu kısmında hüküm uyuşmazlığı ve bu uyuşmazlığın çözüm usulüyle ilgili hususlara yer verilecektir.

\section{A. Genel Olarak}

Hüküm uyuşmazlığ 1 , UMK'nun 24. maddesinde düzenlenmiştir ${ }^{3}$. Madde de hüküm uyuşmazlığı ve şartlarıyla ilgili: "1 nci maddede gösterilen yargl mercilerinden en az ikisi tarafindan, görevle ilgili olmaksızın kesin olarak verilmiş veya kesinleşmiş, birbirine uymayan kararlar arasında hüküm uyuşmazlı̆̆ının varlığının kabul edilebilmesi için bu kararların aynı konuya ve sebebe ilişkin ve en az davacılarının aynı olması ve kararlar arasındaki uyuşmama yüzünden hakkın yerine getirilmesinin olanaksız bulunması gerekir. Ceza kararlarında sanığın, fiilin ve maddi olayların aynı olması hâlinde hüküm uyuşmazlı̆̆ varsayılır. Ilgili kişi veya makam, Uyuşmazlık Mahkemesine başvurarak hüküm uyuşmazlığının giderilmesini isteyebilir. Bu hâlde olumsuz görev uyuşmazlı̆̆ının çıkarılması ile ilgili 15 ve $16 \mathrm{ncl}$ maddelerdeki usul kuralları uygulanır." hükmüne yer verilmiştir.

$\mathrm{Bu}$ uyuşmazlıklarla ilgili inceleme usulünün düzenlendiği UMK'nun 25. maddesinde de: “Hukuk alanindaki hüküm uyuşmazlıklarında Uyuşmazlık Mahkemesi, Danıştay yargılama usulünün bu kanuna aykırı olmayan hükümlerini uygulamak suretiyle anlaşmazlı̆̆ın esasinı da karara bağlar.

Ceza alanındaki hüküm uyuşmazlıklarında Uyuşmazlık Mahkemesi, Ceza Muhakemeleri Usulü Kanunu'nun bu kanuna aykırı olmayan hükümlerini uygular ve esasa ilişkin bir karar vermeksizin sadece o davayı hangi ceza mahkemesinin görüp karara bağlaması gerektiğini belirtmek suretiyle anlaşmazllğı çözer. Kazanılmış haklar saklı tutulur. Uyuşmazlık Mahkemesi hüküm uyuşmazlıklarını dosya üzerinde inceleyerek karara bağlar. Gerekli gördüğ̈̈ hâllerde veya istek üzerine taraflarl dinleyebilir." hükmüne yer verilmiştir.

Madde metinlerinden de anlaşılacağı üzere hüküm uyuşmazlığının oluşumu ve çözümünde hukuk ve ceza uyuşmazlığı olmak üzere ikili bir ayrıma gidilmiş; hukuki konularda hüküm uyuşmazlığından

\footnotetext{
${ }^{3}$ DİNÇ, M. İlhan, "Hüküm Uyuşmazlıkları ve Çözümü”, Danıştay Dergisi, S. 70-71, Ankara, 1988, s. 6-7; YEŞiLL, s. 252.
} 
bahsedebilmesi için; farklı yargı kollarına mensup mahkemelerden en az ikisi tarafindan sebebi, konusu ve taraflardan en az biri ayn olan ve birbiriyle çelişen kesin veya kesinleşmiş kararların bulunması ve birbiriyle çelişen kararlar nedeniyle hakkın yerine getirilmesinin imkânsız olması aranmış, bu tür uyuşmazlıkların çözümünde UM'nin, Danıştay yargılama usulünün ${ }^{4}$ UMK'na aykırı olmayan hükümlerini uygulamak suretiyle uyuşmazlığın esasını da karara bağlayacağı belirtilmiş, cezai konularda hüküm uyuşmazlığından bahsedilebilmesi için ise sanı̆̆ın, fiilin ve maddi olayların aynı olması aranmış ve bu uyuşmazlıkların çözümünde CUMK' ${ }^{5}{ }^{5}$, UMK'na aykırı olmayan hükümleri uygulanmak suretiyle ve esasa ilişkin bir karar verilmeden, o davanın hangi ceza mahkemesince karara bağlanacağının tespit edileceği hüküm altına alınmıştır ${ }^{6}$.

Yine UMK'nun 1. maddesinin 2. fikrasında: “Özel kanun uyarınca hakeme başvurulmasının zorunlu olduğu hâllerde ĕger hakemlik görevi hâkim tarafindan yerine getirilmiş ise bu merci, davanin konusuna göre yukarıdaki fikrada yazll adli veya idari yargı mercilerinden sayllır." denilmek suretiyle hakemlerce verilen kararların da mahkeme kararı olduğu hükme bağlanmıştır. Anılan fikra gereğince hakem kararlarının hüküm uyuşmazlı̆̆ına konu olabilmesi için özel kanunlar uyarınca hakemle çözülmesi zorunlu bir uyuşmazlığın varlığı ile hakemlik görevini bir "hâkim"in yapması aranmıştır".

\section{B. Hüküm Uyușmazlığının Şartları}

Hüküm uyuşmazlığının şartlarına UMK'nun 24. maddesinde yer verilmiştir. Maddedeki düzenlemeye göre bu uyuşmazlığın varlığı için; farklı yargı kollarındaki mahkemelerce verilmiş en az iki farklı hükmün bulunması, verilen hükümlerin esasa ilişkin, kesin ya da kesinleşmiş olması, hukuk davalarında taraflardan en az birinin, davaların konu ve sebebinin aynı olması, ceza davalarında sanık, fail ve fiilin aynı olması ve

${ }^{4}$ Danıştayın yaptığı yargılamalarda IYYUK hükümlerinin uygulanması ve UMK'da 2575 sayılı Danıştay Kanunu'na atıf yapılması nedeniyle hukuki konularla ilgili hüküm uyuşmazlıklarının çözümünde IYYUK hükümleri uygulanacağı sonucuna varılmaktadır.

5 Ceza Muhakemeleri Kanunu yürürlükten kalktığı için uygulanacak kanun CMK'dır.

${ }^{6}$ ANIL, Ayten, "Uyuşmazlık Mahkemesi'nin Kuruluşu ve İşleyişi”, Ankara Üniversitesi Siyasal Bilgiler Fakültesi Dergisi, S. 47/1-2, Ankara, 1992, s. 47; YEŞİL, s. 252; TERCAN, Esas Hakkında, s. 790; DİNÇ, s. 10.

7 TERCAN, Erdal, Farklı Yargı Kollarına Mensup Mahkemeler Arasındaki Hüküm Uyuşmazlığı, Uyuşmazlık Mahkemesi Yayınları, Ankara, 2014, s. 107-108, ("Hüküm Uyuşmazlı̆̆ı"); YEŞíL, s. 261. 
kararlar arasındaki çelişki nedeniyle hakkın yerine getirilmesinin imkânsız olması gerekir. $\mathrm{Bu}$ şartları daha ayrıntılı incelemek gerekirse:

\section{En Az İki Farklı Hükmün Bulunması}

UMK'nun 24. maddesi gereğince hüküm uyuşmazlığının varlığı için adli, idari veya askerî yargı mercilerinden en az ikisi tarafindan verilmiş hükümlerin varlığı gerekir ${ }^{8}$. Aynı yargı düzenindeki mahkemelerce verilen kararlar arasındaki uyuşmazlık o yargı kolunun yüksek mahkemesi tarafından çözüleceğinden bu kararlar hüküm uyuşmazlığına konu olmazlar9. Yine kararlardan birinin mahkemeler tarafından verilmesine rağmen diğer kararın il seçim kurulu ${ }^{10}$, valilik ${ }^{11}$, baro başkanlığ $1^{12}$, kaymakamlık ${ }^{13}$, gümrük müdürlüğü yolcu komisyonu ${ }^{14}$

8 “...Hüküm uyuşmazlığına neden olduğu ileri sürülen kararların, yalnızca idari yargı düzenine dâhil mahkemece verilen bir karar ile bu karara karșl yasal bașvuru yollarından biri olan yargılamanın yenilenmesi istemi üzerine yine aynı mahkemece verilen karara ilişkin bulunduğu, dolaylsıyla ortada,1. maddede gösterilen farkl yargl düzenlerine dâhil en az iki mahkeme tarafindan verilmiş kararlar bulunmadı̆ğ anlaşılmaktadır." Uyuşmazlık Mahkemesi Hukuk Bölümü (HB)'nün 09.02.1998 K.T., 1998/3 E., 1998//5 K. sayılı kararı, (Çalışmada yer verilen Uyuşmazlık Mahkemesi kararları http://www.uyusmazlik.gov.tr/kararlar/kararlar.html. adresinden alınmıştır. Sonraki alıntılarda ayrıca kaynak belirtilmeyecektir); Bu uyuşmazlık bazen üç farklı mahkeme tarafından verilmiş kararlar arasında da doğabilir. Bkz. “...Görevle ilgili olmaksızın aynı konuya ve sebebe ilişkin ve tarafları aynı olan ve aralarındaki çelişki yüzünden hakkın yerine getirilmesinin olanaksı bulunduğu anlaşılan a) Ankara 1.İdare Mahkemesi'nin kararı ile Ankara 10. Sulh Hukuk Mahkemesi'nin kararı arasinda oluşan hüküm uyuşmazlığının Ankara 1.İdare Mahkemesi'nin kararının kaldırılması sureti ile giderilmesine; b) Ankara 1.İdare Mahkemesi'nin kararl ile Ankara 23. Asliye Hukuk Mahkemesinin kararı arasında oluşan hüküm uyuşmazlı̆̆ının Ankara 1.İdare Mahkemesi'nin kararının kaldırlmast sureti ile giderilmesine karar verildi." UM HB'nün 03.3.2014 K.T., 2012/164 E., 2014/143 K. sayılı karar1; GÖZÜBÜYÜK, A. Şeref/TAN, Turgut, İdare Hukuku-İdari Yargılama Hukuku, C. 2, 5. Bas1, Turhan Kitapevi, Ankara, 2012, s. 242; YEŞILI, s. 259 vd.; YİĞİT, Birgül, "Oluşumu, Görev Alanı ve Başvuru Yolları ile Uyuşmazlık Mahkemesi'nin Temel Yapısına Genel Bir Bakış", Uyuşmazlık Mahkemesinin Kuruluşunun 70. Yılı Uluslararası Sempozyumu, (Editör: Ufuk YEŞİL), Uyuşmazlık Mahkemesi Yayınları, Ankara, 2015, s. 220-221; RESULOĞLU, Mustafa, Uyuşmazlık Mahkemesi ve Görev ile Hüküm Uyuşmazlıkları, TODAİE, Yayımlanmamış Uzmanlık Tezi, Ankara, 1988, s. 145-146; KURU, Baki, Hukuk Muhakemeleri Usulü, Demir Demir Yayıncılık, C. 1, İstanbul, 2001, s. 768; TERCAN, Esas Hakkında, s. 794; DİNÇ, s. 9.

${ }^{9}$ UM Ceza Bölümü (CB)'nün 02.3.2015 K.T., 2015/3 E., 2015/3 K. sayılı kararı.

${ }^{10}$ UM HB'nün 14.10.1991 K.T., 1991/35 E., 1991/33 K. say1l karar1.

${ }^{11}$ UM HB'nün 16.5.2005 K.T., 2005/19 E., 2005/37 K. sayıl1 kararı.

${ }^{12}$ UM HB'nün 19.12.2011 K.T., 2011/56E., 2011/259 K. say1l kararı. 
ve Sayıştay ${ }^{15}$ gibi yargı mercii olmayan idari mercilerce verilmesi durumunda iki farklı mahkeme tarafından verilmiş kararlar bulunmadığ için hüküm uyuşmazlığ1 doğmaz ${ }^{16}$. Aynı şekilde yargısal bir faaliyet yerine getirseler de Yargitay Cumhuriyet Başsavcilığ ${ }^{17}$ ve cumhuriyet başsavcılıkları da UMK'nun 1. maddesinde sayılan yargı mercilerinden olmadıklarından verdikleri kararlar hüküm uyuşmazlığına konu olmaz ${ }^{18}$.

UM'nin Hukuk Bölümünde karara bağlanan hüküm uyuşmazlıkları, kural olarak hukuk mahkemeleri, idare ve vergi mahkemeleri ve Askeri Yüksek İdare Mahkemesi (AYIM) kararları arasında; Ceza Bölümünde karara bağlanan hüküm uyuşmazlıkları ise ceza mahkemeleri ile askerî ceza mahkemeleri tarafindan verilen kararlar arasında çıkmaktadır. Ancak 5326 sayılı Kabahatler Kanunu $^{19}$ kapsamında verilen idari yaptırım kararları idari makamlarca verilse de, bu yaptırımlarla ilgili itirazlar istisnalar dişında- sulh ceza mahkemesi tarafindan incelendiğinden sulh ceza mahkemeleriyle idare mahkemeleri arasında da hüküm uyuşmazlığ doğabiliir ${ }^{20}$. Aynı şekilde Danıştay kararı ile asliye ceza mahkemesi kararı arasında da hüküm uyuşmazlığı doğması mümkündür ${ }^{21}$.

\section{Hükümlerin Esasa İlișkin Olması}

UMK'nun 24. maddesinin 1. fikrası gereğince, hüküm uyuşmazlı̆̆ doğabilmesi için verilen kararların görevle ilgili olmaması ve esasa ilişkin olması gerekir ${ }^{22}$. Hukuk davalarında dilekçenin ${ }^{23}$ ve davanın reddi ${ }^{24}$,

${ }^{13}$ UM HB'nün 07.7.2008 K.T., 2008/137 E., 2008/205 K. say1lı karar1.

${ }^{14}$ UM HB'nün 07.3.2005 K.T., 2005/3 E., 2005/15 K. say1lı kararı.

${ }^{15}$ UM HB'nün 14.11.1994 K.T., 1994/28 E., 1994/29 K. sayılı kararı.

${ }^{16}$ DURAN, Lütfi, Uyușmazlık Mahkemesi İçtihatlarına Göre Vazife ve Hüküm İhtilafları, (Yayımlanmamış Doçentlik Tezi), İstanbul, 1950, s. 125; ÇAĞLAYAN, Ramazan, İdari Yargılama Hukuku, 4. Baskı, Seçkin Yayınevi, Ankara, 2014, s. 14243, ("Yargılama"); YEŞIL, s. 262.

${ }^{17}$ UM HB'nün 07.12.2009 K.T., 2009/256 E., 2009/313 K. say1lı karar1.

${ }^{18}$ UM HB'nün 18.11.2002 K.T, 2002/89 E., 2002/76 K. say1lı kararı; YEŞİL, s. 262.

19 31/3/2005 tarihli ve 25772 say1l Resmi Gazete.

${ }^{20}$ UM HB'nün 01.4.2014 K.T., 2013/1148 E., 2014/314 K. sayılı kararı; YEŞİL, s. 263.

${ }^{21}$ UM HB'nün 25.12.1989 K.T., 1989/36 E., 1989/37 K. say1l karar1.

22 “...Uyuşmazlığa konu olayda davacının T.C. Ziraat Bankası A.Ş. ve T. Halk Bankası A.Ş. Mensupları Emekli ve Yardım Sandığ aylık bağlanmasına ilişkin olarak davacının adli yargıdaki davasının reddine karar verirken, idari yargıda davacının T.C. Ziraat Bankası ve T. Halk Bankası Mensupları Emekli ve Yardım Sandiğı Vakfinca emekli aylı̆̆ bağlanması gerektiğ $i$ ve davacının Emekli Sandı̆̆ınca bă̆lanan emekli aylığının iptal edilmesi için yaptığı başvurunun reddine ilişkin dava konusu işlemde hukuka uyarlı görülmediği gerekçesiyle iptaline hükmederek davaların esastan karar verildiği 
yetkisizlik kararı, zaman aşımı, dava ehliyetinin yokluğu ${ }^{25}$ ve davanın açılmamış sayılmasına ilişkin kararlar ile ceza davalarında verilen takipsizlik kararı, yetkisizlik kararı, şartla salıverme ${ }^{26}$, dava şartlarının bulunmadığından davanın reddi, hükmün açıklanmasının geri bırakılması, durma ve düşme kararları da davayı sona erdiren kararlardır. Ancak bu

anlaşılmıştır." UM HB'nün 28.9.2015 K.T., 2014/783 E., 2015/563 K. sayılı kararı; “...Olaylarda, iki ayrı yargı yerinde açılmış davalar nedeniyle görevle ilgili olmaksızın verilmiş kararlar mevcuttur.” UM HB’nün 28.6.1993 K.T, 1993/27 E., 1993/27 K. say1l1 kararı.

23 “...Aralarında hüküm uyuşmazlığı bulunduğu iddia edilen Yargıtay 14. Hukuk Dairesi kararının, ferağa icbar suretiyle tapuya tescil davasının kabulüne ilişkin ...Asliye Hukuk Mahkemesinin kararının temyizi üzerine verilen ve harç ücreti vekalet yönünden bozmaya iliş̧kin bir karar olduğu, Danıştay 6. Dairesi'nin kararının ise imar planının iptaline ilişkin bir davada davanın süresinde açılmamış olması nedeniyle ve süre yönünden reddine ilişkin bir karar bulunduğu görülmekle 24. maddesindeki hüküm uyuşmazliğı için öngörülen koşulların gerçekleşmediği ortadadır." UM HB'nün 23.12.1985 K.T, 1985/30 E., 1985/36 K. sayıl1 kararı.

24 “...Idare Mahkemesince verilen karar Danıştay ilgili Dairesince onanarak kesinleşmiş ise de onama kararının işin esasına yönelik bir karar niteliğinde olmadı̆̆, 2577 sayılı Yasa'nın 14/3-d maddesinde belirtilen idari davaya konu olacak kesin ve yürütülmesi gereken bir işlem olmadiğ yönünde dilekçeler üzerine ilk inceleme aşamasinda verilen kararlardan olduğu kuşkusuzdur ...ve Yasa'nın 24. maddesinde öngörülen koşulların birlikte gerçekleşmemesi karşısııda başvurunun reddi gerekmiştir." UM HB'nün 05.3.2012 K.T., 2011/69 E.,2012/34 K. say1lı karar1.; “...idari yargıda, aynı parselasyon işleminin iptali yolundaki başka bir yargı kararı bulunduğundan bahisle işin esasına girmeden davanın incelenmeksizin reddine karar verildiği; bu bağlamda öncelikle İdare Mahkemesi kararının işin esasına yönelik olmaması nedeniyle hüküm uyuşmazlığının varlığı için gerekli olan davanın esasının karara bağlanması koşulunun gerçekleşmediği...” UM HB'nün 30.9.2013 K.T., 2012/329 E., 2013/1262 K. say1lı kararı.

25 “...Idare Mahkemesince davanın ehliyetsizlik nedeniyle reddine karar verilirken adli yargıda işin esasına girilerek taşınmazın orman olduğu gerekçesiyle orman sinırlandırmasının iptaline ilişkin davanın reddine karar verildiği görülmektedir. ...Koşulları taşımayan başvurunun reddi gerekmiştir.” UM HB'nün 02.6.2014 K.T., 2013/1472 E., 2014/615 K. say1l karar1.

26 “...Somut olayda 4616 sayll Yasa'ya göre verilmiş bulunan kararlar, hükmün özünü ve esasını değiştirmediğinden bir ceza belirlemesi olup duruşma yapılmaksızın evrak üzerinde verilmiş ve itiraza konu kararlardandır. Hüküm, bir kimseye suç isnat edilmesi ve bu iddianın araştırılmasının istenilmesi için açılan ceza davası sonunda verilmiş, davanın esasını halleden, son karardır. Temyiz edilebilmesi hükmün başlıca özelliğini teşkil etmektedir. Açılklanan nedenlerle askerî ve adli yargı yerlerince verilen kararlar 'hüküm' niteliğinde bulunmadĭ̆ından başvurunun reddine karar verilmesi gerekmektedir.” UM CB'nün 31.12.2002 K.T., 2001/161 E., 2002/70 K. say1lı karar1. 
kararlar davanın esasına ilişkin olarak verilmezler ve bu nedenle de hüküm uyuşmazlığına konu olmazlar ${ }^{27}$.

Hukuk davalarında verilen kararlar davanın kabulü ya da reddine ilişkindir. Davanın reddine sadece usulü eksikliklerden dolayı karar verilmez. Ret kararının usule mi yoksa esasa $m ı$ ilişkin olduğu noktasında tereddüt varsa gerekçeye bakılır. Benzer şekilde ceza davalarında verilen kararların her ikisi de mahkûmiyet ya da beraat olabilir. Her iki kararın mahkûmiyet olması ve farklı cezalar içermesi durumunda ${ }^{28}$ bu cezaların infazıyla ilgili tereddüt yaşanacağından bu kararlar arasında da hüküm uyuşmazlı̆̆ doğabilirr ${ }^{29}$.

\section{Hükümlerin Kesin Olması}

Hüküm uyuşmazlığının varlığı için verilen kararların kesin olması gerekir $^{30}$. Bu hususa UMK'nun 24. maddesinde “...kesin olarak verilmiş veya kesinleşmiş... karar" ş̧eklinde yer verilmiştir. Yani kararlardan sadece birinin kesinleşmesi hüküm uyuşmazlığı için yeterli değildir ve hepsinin kesinleşmesi gerekir ${ }^{31}$.

Mahkeme kararlarının kesinleşmesi şeklî ve maddi anlamda olmak üzere iki şekilde gerçekleşir ve hüküm uyuşmazlığına konu kararların şekli anlamda kesinleşmesi, yani karara karşı başvurulabilecek olağan kanun yollarının tüketilmesi yeterlidir ${ }^{32}$.

Verilen karara karşı başvurulacak bir kanun yolu öngörülmemişse bu karar verildiği anda kesinleşir ve bu şekilde kesinleşen kararların da

\footnotetext{
${ }^{27}$ UM HB'nün 24.9.2012 K.T., 2012/47 E., 2012/180 K. say1l karar1; DURAN, s. 126; YEŞİL, s. 263-264; TERCAN, Hüküm Uyuşmazlığı, s. 119,529; DİNÇ, s. 10; YİĞíT, s. 227; TERCAN, Esas Hakkında, s. 789.

28 "...Adli ve askerî yargl yerlerinin mahkûmiyete ilişkin ve birbirlerine uymayan kararları arasında her iki hükme konu olan sanı, fiil ve maddi olayın aynı olmast nedeniyle Yasa'nın 24. maddesindeki koşullar gerçekleşmiş ve iki yargl yerinin kesinleşmiş kararları arasında hüküm uyuşmazlığ oluşmuştur." UM CB'nün 27.6.1983 K.T., 1983/60 E., 1983/417 K. say1lı kararı.

${ }^{29}$ YEŞiL, s. 264; TERCAN, Hüküm Uyuşmazlı̆̆l, s. 124 ve 533; TERCAN, Esas Hakkında, s. 790.

${ }^{30}$ UM HB'nün 28.9.2015 K.T., 2014/783 E., 2015/563 K. sayılı karar1.

31 “...İdare Mahkemesinin kararı, Danıştayca onanmış olmasına karşılık davalı ...Belediye Başkanliğının karar düzeltme başvurusu Danıştay incelemesine sunulmadan dava dosyası Uyuşmazlı Mahkemesine gönderilmiş olduğundan henüz kesinleşmemiştir.” UM HB'nün 28.4.2003 K.T., 2002/88 E., 2003/20 K. sayılı karar1.

${ }^{32}$ YEŞ่LL, s. 265; YİĞİT, s. 223 vd.; DİNÇ, s. 8; TERCAN, Hüküm Uyuşmazlığı, s. 126127; GÖZÜBÜYÜK/TAN, s. 242; RESULOĞLU, s. 148.
} 
hüküm uyuşmazlığına konu olabileceğini belirtmek adına UMK'nun 24. maddesinde "kesin olarak verilmiş" cümlesine yer verilmiştir. Yine öngörülen kanun yollarına ilişkin sürelerin geçirilmesi ya da kanun yolu başvurusu neticesinde kararların kesinleşmesi mümkündür. Bu konuda önemli olan husus, ilgili usul kanunlarına göre kararların kesinleşmiş olmasidir ${ }^{33}$.

\section{Hukuk Davalarında Konu, Sebep ve Taraflardan En Az Birinin Aynı Olması}

Hukuk davalarında hüküm uyuşmazlığından söz edebilmesi için verilen kararların konusu ve sebebinin, taraflardan da sadece birinin ayn olmas1 gerekir. Bu hususa, UMK'nun 24. maddesinin 1. fikrasinda “...ayn konuya ve sebebe ilişkin, taraflarından en az biri aynı olan ...kararlar ..." şeklinde yer verilmiştir.

Davanın konusu, davanın açılmasıyla elde edilmek istenen sonuçtur $^{34}$. Dava konularının aynı olup olmadığını anlamak için kararların hüküm fikraları karşılaştırılır ve aynı hususları ihtiva etmeleri halinde konuların aynı olduğuna karar veriliir ${ }^{35}$. Kararların hüküm fikralarında bir netlik bulunmaması halinde gerekçelerine bakılır. Zira gerekçede de dava konusuyla ilgili hususlara yer verilir ${ }^{36}$.

\footnotetext{
${ }^{33}$ DURAN, s. 130-131; YEŞIL, s. 265; TERCAN, Hüküm Uyuşmazlı̆̆l, s. 126.

34 “...Dava konusu; dava ile elde edilmek istenen sonuçtur. Dava konusunun netice-i talep ve dava sebebi ile karlştırılmaması gerekir. Dava sebebi, daha önce de belirttiğimiz gibi davacının davasını dayandırdı̆̆ $\mathrm{v}$ vakıalardır. Netice-i talep ise; davacının dava açmakla elde etmek istediği hukuki korumadır." UM HB'nün 13.10.2014 K.T, 2014/18 E., 2014/888 K. sayılı kararı.

35 “...Adli yargıda davanın konusu; davacının T.C. Ziraat Bankası A.Ş. ve T. Halk Bankası A.Ş. Mensupları Emekli ve Yardım Sandĭ̆ aylık bağlanmasına ilişkin olup davacının davasının reddine karar verilirken, idari yargida davacının T.C. Ziraat Bankası ve T. Halk Bankası Mensupları Emekli ve Yardım Sandĭ̆ Vakfinca emekli aylı̆̆ bağlanması gerekmekte olup, davacının Emekli Sandı̆̆ınca bağlanan emekli aylığının iptal edilmesi için yaptığı başvurunun reddine ilişkin dava konusu işlemde hukuka uyarlı görülmediği gerekçesiyle iptaline hükmetmiş ve hüküm uyuşmazlı̆̆l olduğu iddia edilen kararlar arasında dava konuları da aynıdır." UM HB'nün 28.9.2015 K.T., 2014/783 E., 2015/563 K. sayılı kararı.

${ }^{36}$ YEŞILL, s. 265 vd; DURAN, s. 137; TERCAN, Hüküm Uyuşmazlı̆̆l, s. 131; TERCAN, Esas Hakkinda, s. 789.
} 
UM, dava konularının aynı olmasıyla ilgili yaptığı incelemede, kararlar arasında tam bir ayniyet aramamakta, hakkın özünü zedeleyen ortak bir paydanın varlığını yeterli kabul etmektedir ${ }^{37}$.

Konuyla ilgili olarak UM verdiği bir kararında, özel mülkiyete ait taşınmazın bir kısmını orman alanına dâhil eden adli yargı kararıyla, aynı taşınmazı özel orman statüsüne sokan idari yargı kararının konularının aynı olduğunu ve bu kararlar sonucu mülkiyet hakkının kullanılmasının imkânsız hâle geldiğini belirtmiştir ${ }^{38}$.

Başka bir kararında ise, idare yargı merciince verilen kararın konusunun "5434 sayll Kanun'un 54. maddesine göre adi malûllük aylı̆̆ bağlanması" olmasına rağmen, adli yargı merciince verilen kararın konusunun "506 sayılı Kanun'un 53. maddesine göre malûllük aylı̆̆ bağlanması" olduğunu ve kararların aynı konuya ilişkin bulunmadığını hükme bağlamıştır ${ }^{39}$.

Hüküm uyuşmazlığına konu kararların konuları dışında sebeplerinin de aynı olması gerekir ${ }^{40}$. Sebeplerin aynı olmasiyla anlatılmak istenen, açılan davalarda davacının haklılı̆̆ını ispat adına ortaya koyduğu nedenlerin ayniyetidir ${ }^{41}$. Davaların açılma sebeplerinin farklı olduğu durumlarda başvuru reddedilir ${ }^{42}$.

37 “...Uyuşmazlık Mahkemesi, önüne gelen uyuşmazlıkların, ayrı yargı kolları önünde farklı yargilama usullerine tabi şekilde incelenmesi ve bu şekilde karara bağlanması nedenleri ile farkl sonuçların ortaya çıkmasına neden olan kararların lafzından ziyade esası, davanın açılmasına neden olan saik yönü ile incelemekte ve davacının dava dilekçesi veya davalının cevap dilekçesindeki nitelemelerden ziyade, açılan davalarla varılmak istenilen nihai amaç kapsamında uyuşmazlığı ele almaktadır." UM HB'nün 13.10.2014 K.T, 2014/18 E., 2014/888 K. say1l karar1.

${ }^{38}$ UM HB'nün 01.10.2012 K.T., 2011/224 E., 2012/190 K. sayılı kararı.

${ }^{39}$ UM HB'nün 17.11.1997 K.T., 1997/32 E., 1997/47 K. say1l kararı.

40 “...2247 sayılı Kanunu'nun 24. maddesinde açıkça 'dava sebebi' kavramı kullanılmıştır. Hüküm uyuşmazlığına konu kararların aynı sebeple açılmış olmasından kasıt, aynı dava sebebine dayanmış olmalarıdır. Bu noktada dava sebebi ile hukuki sebebin karıștırılmaması gerekir. Dava sebebi, davacının davasını dayandırdı̆̆ vakıalardır. Hukuki sebep ise davacının davasına dair nitelendirmesidir. Örneğin bir trafik kazasında yaralanan mağdurun açtı̆̆ı tazminat davasının dava sebebi, 'trafik kazası' iken, hukuki sebebi 'haksı fill' dir." UM HB'nün 13.10.2014 K.T., 2014/18 E., 2014/888 K. say1l karar1.

41 “...Olayımızda her iki davanın sebebi, davacı O. T. 'un T.C. Ziraat Bankası A.Ş. ve T. Halk Bankası A.Ş. Mensupları Emekli ve Yardım Sandığı Vakfi bünyesinde (yaklaşılk 21 yıl) ve Emekli Sandiğına tabi olarak (yaklaşık 3 yıl 3 ay) çalışması ve davacının emeklilik ikramiye ve haklarının çalıştığ hangi kurum tarafindan ödeneceğine ilişkindir. 
UM, hüküm uyuşmazlığıyla ilgili yapılan başvurularda davaların konu ve sebebini birlikte değerlendirmekte, bu iki unsurun ortak hakka ya da vakıalara dayanması halinde ayniyetlerine karar vermektedir ${ }^{43}$.

Hüküm uyuşmazlığının varlığı için aranan diğer bir şart, taraflardan en az birinin aynı olmasıdır ${ }^{44}$. "Taraf" kavramı, dava dilekçesinde kendisi için hukuki koruma isteyen kişi (davacı) ile kendisine karşı hukuki korunma talep edilen (davalı) kişiden oluşan bütündür ${ }^{45}$. Tarafların kararlardaki rolleri aynı olabileceği gibi ${ }^{46}$ farklı da olabilir ${ }^{47}$. Başka bir

Olayımızda davacı hakkında adli ve idari yargı yerlerinde görülen ve çözülen her iki dava sebebi yani maddi vakıalar aynıdır." UM HB'nün 28.9.2015, 2014/783 E., 2015/563 K. sayılı kararı; TERCAN, Hüküm Uyuşmazlı̆̆ , s. 140; YEŞİL, s. 268-269; TERCAN, Esas Hakkinda, s. 798.

42 “...Adli yargl yerinde görülen davanın sebeplerinden birini, ilgilinin vatandaşlık durumu ve nüfus kayıtları olușturmakta; buna karşılık idari yargı yerinde, davanın sebebi vatandaşlı hukuku ile uluslararası anlaşma ve bunlara ilişkin uygulama olduğundan iki dava arasındaki ilişki, bir sebep sonuç ilişkisinden ibaret bulunmaktadır. Yasa'da öngörülen öncelikli koşullardan dava sebeplerinin aynı olması koşulunun gerçekleşmemiş bulunması karşısında başvurunun reddi gerekmektedir.” UM HB'nün 03.5.2004 K.T., 2003/60 E., 2004/17 K. sayılı karar1.

43 “....Her iki davanin konusunu ve sebebini tespit etmek gerekirse her iki davada da dava sebebini, mimari projesine aykırı olarak yapıldiğı iddia edilen tadilatlar, dava konusunu yapılan bu tadilatlar nedeni ile kiracı şirketin dava konusu taşınmazı kullanabilip kullanamayacağl, netice-i taleplerin ise kiracı şirket açısından taşınmazın kullanılmasına devam edilmesi, kiralayan Belediye Başkanlı̆̆ yönünden ise kiracı şirketin taşınmazdan tahliyesi olduğu ortadadır." UM HB'nün 03.3.2014 K.T., 2012/164 E., 2014/143 K. sayılı kararı; TERCAN, Esas Hakkında, s. 789-790; YEŞİL, s. 270; TERCAN, Hüküm Uyuşmazlığı, s. 140.

44 “...Hüküm uyuşmazlığ bulunduğu ileri sürülen idari yargl ve adli yargı kararlarının incelenmesinden davanın taraflarının en az birinin (O.T) ayn olduğu anlaşılmıştır." UM HB'nün 28.9.2015 K.T., 2014/783 E., 2015/143 K. sayılı karar1.

${ }^{45}$ UM HB'nün 18.12.2000 K.T., 2000/60 E., 2000/67 K. say1lı kararı.

46 “...Davanın tarafları yönünden gerek ...İdare Mahkemesinin dosyasında ve gerekse de ....ंड̧ Mahkemesinin dosyasında, davacı ...İ̧sletmeleri A.Ş. tarafindan, davalı Sosyal Güvenlik Kurumu Başkanlığına karşı dava açıldı̆̆ görülmekle dava taraflarının aynı olduğu tespit edilmiştir." UM HB'nün 13.10.2014 K.T., 2014/18 E., 2014/888 K. say1lı kararı.

47 “...Hüküm uyuşmazlığı bulunduğu ileri sürülen idari yargı ve adli yargı kararlarının incelenmesinden ...davanın taraflarının en az birinin(A. Ö) aynı olduğu anlaşılmıştır." UM HB'nün 13.10.2014 K.T., 2013/1607 E., 2014/887 K. say1lı karar1; “...Tüm kararlarda ...Belediye Başkanlı̆̆ yönünden taraflardan en az birinin aynı olması koşulunun gerçekleştiği anlaşılmaktadır.” UM HB'nün 28.4.2003 K.T., 2002/88 E., 2003/20 K. say1l kararı. 
deyişle, bir davada davacı olan taraf, diğer dava da davalı olabilir. Burada önemli olan husus, kararlardaki taraflardan en az birinin aynı olmasıdır ${ }^{48}$.

Davanın tarafları yanında asli müdahil de, taraf olarak kabul edildiği için hüküm uyuşmazlığının çözümünü isteyebilirr ${ }^{49}$. Ancak feri müdahil davada taraf olarak kabul edilmediğinden tek başına hüküm uyuşmazlığının çözümünü isteyemez ${ }^{50}$.

\section{Ceza Davalarında Sanığın, Fiil ve Maddi Olayın Aynı Olması}

UMK'da, ceza dosyalarıyla ilgili hüküm uyuşmazlığı şartları, hukuk dosyalarından farklı düzenlenmiştir. Konuyla ilgili UMK'nun 24. maddesinin 2. fikrasında; "Ceza kararlarında sanığın, fiilin ve maddi olayların aynı olması hâlinde hüküm uyuşmazlı̆̆g var sayılır." ifadesine yer verilmiştir.

Sanık, üzerine atılı suç(lar) nedeniyle hakkında kamu davası açılan ve yargılanması talep edilen kişidir $^{51}$. Ceza davalarında hüküm uyuşmazlığından söz edebilmek için her iki dosyanın sanığının aynı olması gerekir ${ }^{52}$. Yani bir kişinin kararların birisinde sanık, diğerinde müşteki olması durumunda hüküm uyuşmazlığı doğmaz ${ }^{53}$.

Ceza dosyalarında, sanık yanında maddi olay ve fiilin de aynı olması gerekir. Maddi olayın ayniyetiyle anlatılmak istenen; sanığın gerçekleştirdiği iddia edilen ve yargılamaya konu vakıaların her iki kararda da ayn olmasi $^{54}$, fiillerin aynı olmasiyla anlatılmak istenen ise,

\footnotetext{
${ }^{48}$ DİNÇ, s. 10; YEŞİL, s. 270-271; TERCAN, Hüküm Uyuşmazlı̆ğ, s. 145-146; DURAN, s. 141.

49 “...I.F.Y., idari yargıda açılan iptal davasında davacının murisi, adli yargıda açılan davada ise müdahil olduğu hususlarl dikkate alındiğında taraflardan en az birinin (İ.F.Y.) aynı olduğunun kabulü gerekir." UM HB'nün 05.4.2010 K.T., 2010/49 E., 2010/60 K. sayılı kararı.

${ }^{50}$ UM HB'nün 05.12.2012 K.T., 2011/200 E., 2012/212 K. sayılı kararı; YEŞİL, s. 271; TERCAN, Hüküm Uyuşmazlığl, s. 147-148.

51 YENISEY, Feridun/NUHOĞLU, Ayşe, Ceza Muhakemesi Hukuku Ders Kitabı, Bahçeşehir Üniversitesi Yayınları, İstanbul, 2014, s. 148; YEŞİL, s. 271-272; TERCAN, Hüküm Uyuşmazlı̆̆l, s. 535.

${ }^{52}$ UM CB'nün 22.12.1995 K.T., 1995/31 E., 1995/35 K. sayılı kararı.

${ }^{53}$ YEŞILL, s. 272; TERCAN, Hüküm Uyuşmazlı̆̆ , s. 535-536.

54 “...Her iki yargı kararında maddi olay, sanı̆̆ın ...Derneği tarafindan hazırlanmış bulunan "Faşist Teröre Karşı Savaşalım - Dev - Genç" başlıklı bildiriyi dağıtmasından ibarettir. Bu duruma göre maddi olayda birlik mevcuttur.” UM CB'nün 11.4.1983 K.T., 1983/47 E., 1983/149 K. sayılı kararı.
} 
sanığın cezalandırılmasına esas teşkil eden eylemlerin ayniyetidir. Aynı fiille ilgili farklı mahkemelerce farklı hukuki niteleme yapılarak farklı cezalar verilmiş olmasının fiillerin ayniyetine etkisi yoktur. Burada önemli olan husus, her iki kararda da sanığın aynı fiil(ler) nedeniyle cezalandırılmasıdır ${ }^{55}$.

\section{6. Çeliş̧i Nedeniyle Hakkın Yerine Getirilmesinin İmkânsız Olması}

Hüküm uyuşmazlığının varlığı için diğer bir şart, verilen kararlar arasındaki çelişki nedeniyle hakkın yerine getirilememesi, yani kararların icra edilememesidir ${ }^{56}$. Kararlar arasındaki bu çelişki, genellikle ikinci kararın infazı aşamasında ortaya çıkar ${ }^{57}$.

Kararlar arasındaki çelişkinin nasıl ortaya çıktığı önemli değildir. Çelişki, hukuk davalarında davacının talebinin mahkemelerden biri tarafından kabul edilip diğeri tarafından reddedilmesi şeklinde olabileceği gibi $^{58}$, birden fazla yönü bulunan davalarda, kararlardan birinin davanın esasıyla ilgili hususları ihtiva etmesine rağmen, diğerinde etmemesi şeklinde de olabilir ${ }^{59}$. Yine, ceza davalarında kararlardan birinin mahkûmiyet olmasına rağmen diğerinin beraat olması veya her iki kararın mahkûmiyet olması ve bu kararlarda farklı cezalara hükmedilmesi sebebiyle hangisinin infazının yapılacağı konusunda tereddüt yaşanması

\footnotetext{
55 “...Her iki mahkemenin, kararlarında esas aldıkları bildiri içeriği ve buna göre fiil yani işlenen suç aynıdır." UM CB'nün 11.4.1983 K.T., 1983/47 E., 1983/149 K. sayılı kararı.

56 “...Hüküm uyuşmazlı̆̆ına konu ...İdare Mahkemesinin kararı ile arazinin toplam ...hektarlık kısmının özel orman sayılmasına ilișkin ișlemin hukuken geçerli olduğuna karar verilip işlemin iptali talebi reddedilerek mülkiyet hakkında tasarruf yetkisinin sınırlanması sonucu doğmuş ancak ...Asliye Hukuk Mahkemesinin kararı ile hukuki açıdan haksız bir fiil ve el atma kabulü ile el atmanın önlenmesi ile özel orman kararının iptali ve tapudaki özel orman şerhinin kaldırılmasına karar verilmiştir. Böylece adli ve idari yarg yerlerinde verilen çelişik kararlar nedeniyle davaya konu arazinin mülkiyet hakkının tam olarak kullanımı olanaksız hâle gelmiştir." UM HB'nün 01.10.2012 K.T., 2011/224 E., 2012/190 K. sayılı kararı.

${ }^{57}$ DURAN, s. 131; YİĞIT, s. 229 vd.; YEŞILL, s. 275-276; TERCAN, Hüküm Uyuşmazlığı, s. 150,160; DİNÇ, s. 13; ÇAĞLAYAN, Yargılama, s. 142-143.

58 “...Davacının, sağllk gideri olarak eksik ödenen kısmın ödenmesi talebinin reddine ilişkin idari yargıda verilen karara karşılık adli yargıda davanın kabulü ile malzeme bedelinin ödenmesine karar verildiği; kararlar arasındaki çelişki nedeniyle hakkın yerine getirilmesinin olanaksı hâle geldiği..." UM HB'nün 05.5.2014 K.T., 2013/665 E., 2014/501 K. say1l1 karar1.

${ }^{59}$ YEŞiL, s. 276; TERCAN, Esas Hakkında, s. 791.
} 
halinde de çelişki doğabilir ${ }^{60}$. Ancak her iki kararın beraat olması halinde, kararlar arasında çelişki bulunmayacağı ve kararlar hakkın yerine getirilmesine engel teşkil etmeyeceği için hüküm uyuşmazlığı doğmaz ${ }^{61}$.

Hukuk davalarında kararlar arasındaki çelişki nedeniyle hüküm uyuşmazlığı doğabilmesi için kararların konu ve sebebiyle taraflardan en az birinin aynı olması gerekir. Bu unsurları taşımayan kararlar birbirinden ayrı icra edilebildikleri için aralarında çelişki doğmaz ${ }^{62}$. Benzer şekilde, davalardan birinde davacının talebinin reddedilip, diğerinde kabul edilmesi durumunda ${ }^{63}$; reddedilen kararın davacı lehine bir hak doğurmaması ve bu kararla ilgili yerine getirilmesi mümkün bir hakkın bulunmaması nedeniyle bu kararlar arasında da çelişki doğmaz ${ }^{64}$.

UM, kararlar arasındaki çelişkiyi hakkın yerine getirilip getirilememesi açısından değerlendirmekte olup, kararların icrası açısından değerlendirmemektedir. Mahkeme verdiği bir kararında; “...idare mahkemesi kararı ile işyerinde çalıştırıllp kuruma bildirilmeyen işçi olmadiğı tespit edilmiş olmasına rağmen, iş mahkemesi kararı ile işyerinde çalıştırllip kuruma bildirilmeyen işçi olduğu sonucuna varılmıştır. Bu itibarla idare mahkemesi ile iş mahkemesi kararları arasında oluşan çelişki nedeni ile davacı yönünden hakkın yerine getirilmesi olanaksı hale gelmiştir." diyerek kararlar arasında hüküm uyuşmazlığı bulunduğuna karar vermiştir ${ }^{65}$.

Hüküm uyuşmazlığının varlığı için kararlar arasında çelişki yanında, bu çelişki nedeniyle hakkın yerine getirilmesinin de imkânsız olması gerekir ${ }^{66}$. Hakkın yerine getirilememesi; kesinleşmiş bir karara

${ }^{60}$ UM CB'nün 27.6.1983 K.T., 1983/60 E., 1983/417 K. sayılı kararı.

${ }^{61}$ TERCAN, Hüküm Uyuşmazlı̆̆l, s. 154, 542; YEŞİL, s. 276.

62 “...Köyler arasındaki sinırın idarece tespiti ile ilçe belediye ve köy idari sinırlarının, kadastrosu yapılacak yerlerde çalışma alanı sınırı olarak alınmasının, farklı amaç ve farklı sonuca yönelik olmaları itibariyle idare ve kadastro mahkemesi kararlarının birbiriyle çelişstiğinden söz edilemez." UM HB'nün, 03.7.1995 K.T., 1995/25 E., 1995/29 K. sayıl1 karar1.

${ }^{63}$ UM HB’nün, 22.02.1999 K.T.,1998/75 E., 1999/4 K. sayıl1 kararı.

${ }^{64}$ UM HB'nün, 05.7.1989 K.T.,1989/14 E., 1989/15 K. say1l1 kararı.

${ }^{65}$ UM HB'nün 13.10.2014 K.T., 2014/18 E., 2014/888 K. say1l karar1.

66 “...İdari yargıda yapılan yargılama sonucu idari işlemin iptali ile davacının Emekli Sandı̆̆ından olan emeklilik ayliğının iptal edilmesine karar verilirken, adli yargıda davacının T.C. Ziraat Bankası A.Ş. ve T. Halk Bankası A.Ş. Mensupları Emekli ve Yardım Sandı̆̆ aylık bağlanmasına ilişkin olarak davanın reddine karar verilmişstir. İdari yargl yerinde verilen karar ile adli yarglda verilen kararlar birlikte 
rağmen bu kararın icra edilememesi ve hak sahibinin aynı konuyla ilgili verilmiş başka bir mahkeme kararı nedeniyle hakkını alamamasıdır ${ }^{67}$.

UM, bir kararında hakkın yerine getirilmesinin imkânsızlığını şu şekilde ifade etmiştir: “...Hakkın yerine getirilmesinin olanaksız bulunması durumu, davacı yönünden sübjektif bir nitelik taşımakta ve yargı kararı ile kendisine tanınmış bir hakkın yerine getirilmemesi söz konusu iken; davalı idare yönünden ilamı yerine getirmekle yükümlü olması bakımından objektif bir nitelik taşımakta ve davacıya yargı kararı ile tanınmış olan bir hakkın idarece yerine getirilmesinin olanaksızlı̆̆ını ifade etmektedir. "68

Kararlar arasında çelişki bulunsa bile; bu durumun kararların infazını etkilememesi ${ }^{69}$, birinin varlığının diğerinin uygulanmasına engel teşkil etmemesi ${ }^{70}$, kararın icrası ${ }^{71}$ ve infazının mümkün olması ${ }^{72}$, hak

değerlendirildiğinde davacının hakkının yerine getirilmesi olanaksı hâle getirilmiştir." UM HB'nün 28.9.2015 K.T., 2014/783 E., 2015/563 K. sayılı karar1.

67 “...Hüküm uyuşmazlığının giderilmesi istemiyle başvuru vergi dairesi tarafindan yapılmışır. Danıştay, bozma ve iptal kararı vergi dairesinin vergi alacağının tahsili yolunu kapatmış değildir. Zira bu idare vergi alacağını borçlunun diğer mallarından takip ve tahsil olanağına her zaman sahiptir. Borçlunun bu araçtan başka mal varlığı bulunmadı̆̆ yolunda öne sürülmüss ve kanıtlanmış bir iddia da yoktur. Öte yandan asliye hukuk mahkemesinin satışın iptali isteğinin reddine dair kararı da araç üzerinde mülkiyet muhafaza hakkı bulunan ilk satıcinın aracin bedelini dava yoluyla tahsiline engel değildir. Esasen kararda bu hak sakl tutulmuştur. Bu durumda 'hakkın yerine getirilmesinin olanaksız bulunması' koşulunun gerçekleşmediği anlaşılmaktadır." UM HB'nün 14.10.1991 K.T., 1991/17 E., 1991/26 K. sayılı karar1.

${ }^{68}$ UM HB'nün 02.02.2009 K.T., 2008/134 E., 2009/17 K. sayılı karar1.

69 “...Adlî Yargı merciince müdahalenin men'i ve eski hale iadesi yolunda verilen karar, hakkın yerine getirilmesini olanaksız kılmamaktadır." UM HB'nün , 04.02.2013 K.T., 2012/176 E., 2013/172 K. say1l karar1.

70 “...SSirket vekili tarafindan, anılan kararlarda şirketin 31.12 .2005 tarihli mali tablolarının mevzuata uygunluğu konusunda çelişki olduğu; bu çelişkinin varliğl sebebiyle şirket mali tablolarının kesinleşmediği, bu mali tablolardan çıkan hakların kullanılamadı̆̆ ileri sürülmüs ise de 2499 sayıl Sermaye Piyasası Kanunu'nun 47/A maddesi uyarınca idari para cezası verilmesine ilişsin işlemlerin iptali yolundaki ...Sulh Ceza Mahkemesinin kararının, şirketin mali tablolarının kesinleşmesi, bu mali tablolardan çıkan hakların kullanılamamasıyla ilişkilendirilmesi söz konusu olmayacağı gibi bu kararlardan birinin diğerinin uygulanmasina engel teşkil etmediğinden kararlar arasındaki çelişki nedeniyle hakkın yerine getirilmesinin olanaksız bulunması koşulunun da gerçekleşmediği anlaşılmış olup hüküm uyuşmazlı̆̆ından söz edilemeyeceği açıktır." UM HB'nün 30.12.2013 K.T., 2013/63 E., 2013/1754 K. say1lı karar1; “...idari yargl yerindeki davaya konu ihalenin iptali isteminin reddine ilişkin karar, adli yargl yerinde açılan maddi alacakların ödenmesi istemine ilişkin davanın kabulüne ilişkin kararın 
sahibinin hakkını almış olmas ${ }^{73}$, başvurucuya mahkeme kararı ile tanınmış bir hak bulunmamas ${ }^{74}$ durumlarında hakkın yerine getirilmesinin imkânsızlığından söz edilemeyeceğinden hüküm uyuşmazlığı da doğmaz ${ }^{75}$.

uygulanmasına engel teşkil etmediğinden kararlar arasındaki çelişki nedeniyle hakkın yerine getirilmesinin olanaksız bulunması koşulunun da gerçekleşmediği açıktır." UM HB'nün 17.4.2014 K.T., 2013/1515 E., 2014/712 K. sayıl1 karar1; “...Valiliğin idari tedbir niteliği taşıyan men kararının iptali yolundaki idari yargı kararı, üstün hakkın saptanmasına ilişkin adli yargı kararının uygulanmasına engel teşkil etmediğinden hakkın yerine getirilmesinin imkânsızlı̆̆ından söz edilemez." UM HB'nün 13.6.2005 K.T., 2004/87 E., 2005/45 K. say1lı kararı.

71 “...Idari yargl yerince verilen iptal kararı, idarece yerine getirildiğinden birbiriyle çelișen adli ve idari yargl kararlarl yüzünden hakkın yerine getirilmesinin olanaksız bulunması koşulu geçekleşmemiştir.” UM HB'nün 16.5.1983 K.T., 1982/6 E., 1983/24 K. say1lı kararı.

72 “...Kararın gerekçesi gözetildiğinde tahliyeye ilişkin işlemin yetkili mercii olan mülki idare amirliğince verilmediği, işlemin kesin ve yürütülebilir bir işlem niteliği taşımadiğ kesinleşen adli yargı kararının infazında engel bir durumun olmadığ $\breve{l}$, İare Mahkemesi kararının onama gerekçesine göre yetkili mercie müracaatla işlem tesis ettirilmesi hâlinde infaz kabiliyetinin bulunduğu nedenleriyle hakkın yerine getirilmesinin olanaksızlı̆ı̆ndan söz edilemeyeceği açıktır.” UM HB'nün, 5.3.2012 K.T., 2011/69 E., 2012/34 K. sayıl1 kararı.

73 “...IIzale-yi şuyu kararı uyarınca verilen satış kararı üzerine satılan, ihale ve satışı kesinleşen, mülkiyeti bu ihale ile alıcısına geçen ve alıcının tamamına malik olmak suretiyle paydaşlı̆̆ın giderildiği taşınmaz ile ilgili adli yargl yerinin izale-yi şuyu kararı, infaz olduğundan ve esasen idari yargı yerince karar verildiği tarihte, taşınmazın tamamı alıcının mülkiyetine geçip paydaşlık kalmadiğından birbiriyle çelişen adli ve idari yargı kararları yüzünden hakkın yerine getirilmesinin olanaksız bulunması koşulu gerçekleşmemektedir.” UM HB'nün, 31.01.1983 K.T., 1980/5 E., 1983/13 K. say1lı karar1.

74 “...F.K. açtığı davada borcunun bulunmadı̆̆ını ispatlayamamış ve davası reddedilmiș olduğundan adı geçenin, yargl kararı ile kendisine tanınmıș bir hakkının bulunduğundan da söz etmek olanaksızdır." UM HB'nün, 12.6.2000 K.T., 2000/7 E., 2000/17 K. sayıl1 kararı.

75 “...Idari yargı yerinde açılan davada davacıların gayrimenkuller üzerindeki takyidatların kaldırılması istemleri yerinde görülerek davanın iptalle sonuçlanıp kesinleştiği ve adli yargl yerinde görülen davaların da retle sonuçlanıp kesinleştikleri, davalardaki konu ve dava sebebinin aynı olması koşulunun oluşmadiğı anlaşılmış ise de tarafları yönünden ayn sonuçların doğduğu gözetildiğinde Maliye Hazinesi yönünden hakkın yerine getirilmesinin imkânsızlı̆ııdan söz edilmesi olanaksızdır." UM HB'nün, 19.12.2011 K.T., 2010/134 E., 2011/254 K. sayılı kararı; YEŞIL, s. 280; TERCAN, Hüküm Uyuşmazlı̆̆ , s. $150 \mathrm{vd.}$ 


\section{Hüküm Uyuşmazlığının Çözüm Usulü}

Hüküm uyuşmazlığının çözüm usulüyle ilgili UMK'nun 24. maddesinin 3. fikrasında; "İlgili kişi veya makam Uyuşmazlık Mahkemesine başvurarak hüküm uyuşmazlı̆̆ının giderilmesini isteyebilir. $B u$ hâlde olumsuz görev uyuşmazlı̆ğnın çıkarılması ile ilgili 15 ve $16 \mathrm{nc \imath}$ maddelerdeki usul kuralları uygulanır." ifadelerine yer verilmiştir. Maddeden de anlaşılacağı üzere hüküm uyuşmazlığının çözümüyle ilgili ayrı usul kuralları belirlenmemiş olup, olumsuz görev uyuşmazlığına ilişkin hükümler uygulanacaktır. $\mathrm{Bu}$ nedenle hüküm uyuşmazlı̆̆ının çözüm usulünün, olumsuz görev uyuşmazlığında olduğu gibi; ilgili kişi ya da mercii tarafından yapılacak işlemler, yargı mercilerince yapılacak işlemler, UM tarafından yapılacak işlemler ve UM kararından sonra yapılacak işlemler olarak farklı başlıklarda ele alınmasında fayda vardır.

\section{1. İlgili Kişi Ya da Mercii Tarafından Yapılacak İşlemler}

UMK'nun 24. maddesinin 3. fikrasinda "Illgili kişi veya makam, Uyuşmazlık Mahkemesine başvurarak hüküm uyuşmazlı̆̆ının giderilmesini isteyebilir." hükmüne yer verilse de "ilgili kişi" nin kim olduğuyla ilgili bir hükme yer verilmemiştir. İlgili kişi, hukuk davalarında çelişkili kararlar nedeniyle hakkını alamayan taraf ve asli müdahili, ${ }^{76}$ ceza davalarında ise davanın tarafları ve müdahili ifade eder. İlgili makam ise cumhuriyet savcisidir ${ }^{77}$.

Hukuk davalarında hüküm uyuşmazlığının çözümünü yalnızca davanın tarafları isteyebilir. Tarafların talebi olmadan kararı veren mahkemeler hüküm uyuşmazlığının çözümü için UM'ne başvuramazlar. Taraflar bu davalarda, uyuşmazlığın çözümü için doğrudan UM'ne başvurabilecekleri gibi (UMK md. 24/3), olumsuz görev uyuşmazlığına yapılan atıf nedeniyle son kararı veren mahkemeye de başvurabilirler ${ }^{78}$.

Ceza davalarında ise taraflar, iddia makami ${ }^{79}$ ve UMK'nun 37. maddesi gereğince müdahiller, yerel mahkemeden dosyanın UM'ne

\footnotetext{
${ }^{76}$ UM HB'nün 05.12.2012 K.T., 2011/200 E., 2012/212 K. say1lı karar1.

${ }^{77}$ YEŞİL, s. 280 vd.; TERCAN, Esas Hakkında, s. 792-793; DİNÇ, Hüküm Uyuşmazlığı, s. 19.

${ }^{78}$ DİNÇ, Hüküm Uyuşmazlı̆̆ı, s. 19; YEŞILL, s. 282-283.

79 “...Aynı sanık hakkında aynı suçtan dolayı biri adli yargıya, diğeri askerî yargıya ait olmak üzere iki kesin hüküm bulunduğu, temyiz inceleme mercilerinin ayrı olması nedeniyle ihtilafin yazılı emir yolu ile çözülmesinin mümkün olmadığı, ortada oluşmuş bir hüküm uyuşmazlığl bulunduğundan ihtilafin Uyuşmazlık Mahkemesince çözümlenmesi gerektiği gerekçeleri ile yazılı emir yolu ile bozma isteminin reddine karar
} 
gönderilmesini isteyebilecekleri gibi kendileri de doğrudan UM'ne başvurabilirler ${ }^{80}$.

Hüküm uyuşmazlığ başvurucunun başvurusunda hukuki bir yarar ve menfaatinin olmasi ${ }^{81}$ ve bu menfaatin yargılamanın her aşamasında bulunmasıdır ${ }^{82}$. Yani sadece dava açı1ırken değil, hüküm uyuşmazlığı başvurusu sırasında da hukuki yarar mevcut olmalıdır.

Başvuru dilekçesinde hüküm uyuşmazlığına konu kararlar, taraflar ve bu kararlar arasında oluştuğu ileri sürülen çelişki ile bu çelişki nedeniyle yerine getirilmesi imkânsız hakların neler olduğu belirtilmelidir $^{83}$.

Hüküm uyuşmazlığının çözümüyle ilgili UMK'da öngörülmüş bir başvuru süresi yoktur. Ancak hukuk davalarıyla ilgili başvurunun ilamların icrası için öngörülen zamanaşımı süresi dolana kadar, ceza davalarıyla ilgili başvurunun ise TCK'daki düzenleme nedeniyle her zaman yapılabileceği düşünülmektedir. UM'nin verdiği kararların kesin olması nedeniyle bir kez bu uyuşmazlığın çözümü istenebilir. Yapılan başvurulardan UMK'nun 34. maddesi gereğince herhangi bir vergi ve harç alınmaz.

\section{Yargı Mercilerince Yapılacak İşlemler}

Yarg1 mercilerince yapılacak işlemlere, UMK'nun 24. maddesi yollamasıyla 15. maddesinde yer verilmiştir. Düzenlemeye göre son kararı veren mahkeme, hukuk dosyalarında verdiği kararın kesinleşmesinden sonra taraflardan birinin talebi üzerine, ceza dosyalarında ise resen, ilk karara ait dosyayı da temin ederek kendi dosyasılyla birlikte UM'ne gönderir ${ }^{84}$.

vermiştir. ...Askerî Savcllı̆̆ oluşan hüküm uyuşmazliğının çözümü için dosyayı Uyuşmazlık Mahkemesine göndermiştir.” UM CB'nün 27.6.1983 K.T., 1983/60 E., 1983/417 K. sayılı karar1.

${ }^{80}$ YEŞ่̇L, s. 283; TERCAN, Hüküm Uyuşmazlı̆̆ı, s. 544; DİNÇ, Hüküm Uyuşmazlı̆̆ı, s. 19.

${ }^{81}$ ÇAĞLAYAN, Yargılama, s. 507; YEŞİL, s. 281.

${ }^{82}$ Danıştay 7. Dairesinin 07.3.1996 K.T., 1996/5890 E., 1996/820 K. sayılı kararı.

${ }^{83}$ BARUTOĞLU, Tulez, "Uyuşmazlık Mahkemesine Başvuru Yolları", Adalet Dergisi, S.3, Ankara, 1986, s. 156; TERCAN, Esas Hakkında, s. 795; YEŞIL, s. 283; TERCAN, Hüküm Uyuşmazlığl, s. 171; RESULOĞLU, s. 149-150.

${ }^{84}$ YEŞİL, s. 290; BARUTOĞLU, s. 138; DİNÇ, Hüküm Uyuşmazlı̆̆ı, s. 19. 


\section{Uyuşmazlık Mahkemesince Yapılacak İşlemler}

UM, yapılan başvuruları usule ve esasa ilişkin olmak üzere iki başlıkta incelemektedir.

\section{a. Usule İlişkin inceleme}

Hüküm uyuşmazlığının çözümünde UM tarafından yapılacak işlemlere UMK'nun 24. maddesi yollamasıyla 16. maddesinde yer verilmiştir. $\mathrm{Bu}$ maddeye göre $\mathrm{UM}$, hüküm uyuşmazlığının çözümü talepleriyle ilgili önce ilk inceleme yaparak dosyada eksiklik bulunup bulunmadığını kontrol eder. Eksiklik bulunması halinde de eksiklikleri tamamlatır. İlk inceleme esnasında ilgili yargı kollarının başsavcılarından görüş istenebilir. Ancak görüş istenilmesi zorunlu değildir. Başsavcılardan görüş istenmesi, görüşlerin gelmesi ya da gelmemesi hâlinde hüküm uyuşmazlığ neticesinde kararlar arasında hüküm uyuşmazlığı bulunmadığ 1 anlaşılırsa başvurunun reddine ${ }^{85}$, şartların varlığı hâlinde ise başvurunun kabulüyle kararlar arasında hüküm uyuşmazlığı bulunduğuna karar verilir ${ }^{86}$.

Bu karardan sonra hüküm uyuşmazlığı başvurusuna ilişkin dilekçe ve ekleri öngörülen sürede cevap vermesi amacıyla dosyanın diğer tarafına gönderilir ${ }^{87}$. Gelen cevap dilekçesi ve ekleri bu kez uyuşmazlığın çözümünü isteyen tarafa gönderilir ve dosyadaki eksiklerin tamamlanmasının ardından belirlenen günde dosyanın esasının görüşülmesine karar verilirr ${ }^{88}$.

85 “...2247 sayılı Yasa'nın 24. maddesinde öngörülen 'konu ve dava sebebinin aynı olması', 'hakkın yerine getirilmesinin imkansız bulunması' koşullarını taşımayan başvurunun reddi gerekmiştir.” UM HB'nün 30.12.2013 K.T., 2013/64 E., 2013/1755 K. sayılı kararı.

86 “...Belirtilen nedenlerle İstanbul 2. Vergi Mahkemesi ile İstanbul 7. Asliye Ticaret Mahkemesi kararları arasında 2247 sayılı Yasa'nın 24.maddesinde öngörülen koşulların gerçekleştiği, verilen kararlar arasında hüküm uyuşmazlı̆̆ bulunduğuna karar verilmiştir.” UM HB'nün 21.5.2012 K.T., 2010/95 E., 2012/93 K. sayılı kararı.

${ }^{87}$ TERCAN, Esas Hakkında, s. 796-797; DİNÇ, s. 19; BARUTOĞLU, s. 138; ÇAĞLAYAN, Yargılama, s. 134; RESULOĞLU, s. 120; YEŞİL, s. 291-292; TERCAN, Hüküm Uyuşmazlığı, s. 173.

88 “...2247 sayıl Yasanın 25. maddesi hükümleri uyarınca; a) İdari Yargılama Usulü Yasası gözetilerek Uyuşmazlık Mahkemesine yapılan başvuruya ait dilekçe ve eklerinin otuz gün içinde yanıt verilmek üzere ...Ticaret ve Sanayi A.Ş.' ne bildirilmesine, anılan Şirketçe verilen yanıtın karşı tarafa tebliği suretiyle dosyanın tekemmülünün sağlanmasına, b) Usulü işlemler tamamlandıktan ve esas hakkındaki rapor yazıldıktan 


\section{b. Esasa İlişkin İnceleme}

UM'nin esastan inceleyeceği dosyalarla ilgili uyması gereken kurallar UMK'nun 25. maddesinde düzenlenmiştir. Maddede; "Hukuk alanındaki hüküm uyuşmazlıklarında Uyuşmazlık Mahkemesi, Danıştay yargılama usulünün bu kanuna aykırl olmayan hükümlerini uygulamak suretiyle anlaşmazlığın esasını da karara bağlar.

Ceza alanindaki hüküm uyuşmazlıklarında Uyuşmazlık Mahkemesi, Ceza Muhakemeleri Usulü Kanunu'nun bu kanuna aykırı olmayan hükümlerini uygular ve esasa ilişkin bir karar vermeksizin sadece o davayı hangi ceza mahkemesinin görüp karara bağlaması gerektiğini belirtmek suretiyle anlaşmazlığı çözer. Kazanılmış haklar saklı tutulur.

Uyuşmazlık Mahkemesi hüküm uyuşmazlıklarını dosya üzerinde inceleyerek karara bağlar. Gerekli gördü̈̆̈̈ hâllerde veya istek üzerine tarafları dinleyebilir. " hükmüne yer verilmiştir

UMK'da, hukuk dosyalarında 2575 sayılı Danıştay Kanunu'nun ${ }^{89}$, ceza dosyalarında da CMK'nun, UMK'na aykırı olmayan hükümlerinin uygulanması suretiyle uyuşmazlıkların çözüleceği belirtilmiştir. Mahkeme, UMK'nun 25. maddesinin 3. fikrası gereğince tarafları dinleyebilirr $^{90} ; 35$. maddesi gereğince de dosyayla ilgili her türlü belge ve bilgiyi isteyebilir.

UMK'nun 25. maddesinden de anlaşılacağı üzere, hukuk ve ceza uyuşmazlıklarının çözüm usulleri farklıdır ve bu uyuşmazlıkların çözüm usullerinin ayrı başlıklarda incelenmesi faydalı olacaktır.

\section{aa. Hukuk Dosyalarıyla İlgili Hüküm Uyuşmazlıklarının Çözüm Usulü}

Hukuk dosyalarının çözümünde atıf yapılan İdari Yargılama Usul Kanunu (IYUK)'nda resen araştırma ilkesi geçerlidir (md. 20). Bu ilke gereğince UM uyuşmazlıkları çözerken; her türlü araştırmayı yapabilir, dosyayla ilgili belge toplayabilir, tanık dinleyebilir, bilirkişi incelemesi yaptırabilir ve uygun görmesi halinde duruşma yapabilir (IYUK md. 17) ${ }^{91}$.

sonra Başkanlıkça belirlenecek günde işin esasının görüşülmesine karar verildi... ” UM HB'nün 21.5.2012 K.T., 2010/95 E., 2012/93 K. say1l karar1.

${ }^{89}$ 20.01.1982 tarihli ve 17580 say1l1 Resmi Gazete.

${ }^{90}$ DİNÇ, s. 21; YEŞILL, s. 293-294; TERCAN, Esas Hakkında, s. 796-797; DURAN, s. 155.

${ }^{91}$ YEŞİL, s. 294; DURAN, s. 155; TERCAN, Hüküm Uyuşmazlı̆̆ı, s. 176. 
UMK'nun 25. maddesinin 1. fikrası gereğince UM, hukuk dosyalarıyla ilgili uyuşmazlıkları çözerken işin esasını da karara bağlar ve bu kapsam da üç türlü karar verir. Bunlar, başvurunun reddi, kararlardan birinin kaldırılıp diğerinin olaya uygulanması ve her iki kararın da kaldırılarak dava konusu olayla ilgili yeni bir karar verilmesidir ${ }^{92}$.

$\mathrm{UM}$, şartları taşımayan başvurunun reddine karar verir ${ }^{93}$. Başvuru reddedilse de, uyuşmazlığa konu kararlar kesinleşmiş olduklarından ilgili mercilerce gerekleri yerine getirilir ${ }^{94}$.

UM'nin yaptığı inceleme neticesinde kararlar arasında hüküm uyuşmazlığı bulunduğunu tespit ederse dosyanın esasına girip uyuşmazlığı nasıl çözeceğine karar verir. Bu bağlamda; kararlardan birinin uyuşmazlık konusu olaya uygulanmasına ve diğer(ler)inin kaldırılmasına karar verebileceği gibi, uyuşmazlığın çözümü için kararların yeterli olmaması halinde hepsini kaldırarak dosyanın esası hakkında kendisi yeni bir karar verebilir. UM'ne hüküm uyuşmazlı̆̆ının çözümünde tanınan bu yetki, yani kesin hükümleri kaldırabilme yetkisi başka hiçbir mahkemeye verilmemiştir ${ }^{95}$.

UM, kararlardan birinin olaya uygulanmasına hükmettiği başvurularda dosyanın esasına girmekte ve ilk derece mahkemelerince mevcut belge ve delillere göre karar verilip verilmediğini de değerlendirmektedir ${ }^{96}$. Bu tür başvurularda UM, kendisi dosyanın esasıyla ilgili bir karar vermemekte, uygulanmasına onay verdiği kararın önündeki hukuki engelleri kaldırmaktadır ${ }^{97}$. Uyuşmazlığın bu şekilde çözümüyle

\footnotetext{
${ }^{92}$ BARUTOĞLU, s. 157; DİNÇ, s. 20; YEŞİL, s. 294; TERCAN, Hüküm Uyuşmazlığı, s. 182.

${ }^{93}$ UM HB'nün 01.6.2015 K.T., 2014/932 E., 2015/343 K. say1li; 17.4.2014 K.T., 2013/1515 E., 2014/712 K. say1l1; 02.6.2014 K.T., 2013/1472 E., 2014/615 K. say1l1; 30.12.2013 K.T., 2013/285 E., 2013/1756 K. say1l1; 30.12.2013 K.T., 2013/64 E., 2013/1755 K. say1l ve 30.12.2013 K.T., 2013/63 E., 2013/1754 K. say1l kararlar1.

${ }^{94}$ TERCAN, Esas Hakkında, s. 797; YEȘİL, s. 294.

${ }^{95}$ YEŞiL, s. 295; DURAN, s. 155-156; TERCAN, Esas Hakkında, s. 798 vd.

96 “...Türkiye İstatistik Kurumu Edirne Bölge Müdürlüğ̈̈nde sözleşmeli TÜIK uzmanı olarak görev yapan A.Ö.ye 18.11.2005-14.01.20009 tarihleri arasinda yersiz olarak ödenen denetim tazminatının geri istenilmesine ilişkin işlemin hukuka uygun olduğunun saptanması karşısında...” UM HB'nün 13.10.2014 K.T., 2013/1607 E., 2014/887 K. sayılı kararı; TERCAN, Hüküm Uyuşmazlı̆̆ı, s. 183-184; YEŞİL, s. 295; DİNÇ, s. 20.

97 “...Ecri misil ihbarnamesinin iptali için açılan dava sonunda, davanın reddine karar veren ...Idare Mahkemesi kararının kaldırılması, hukuk ve usule uygun bulunan ...Asliye Hukuk Mahkemesinin kararının kabulü ve bu surette hüküm uyuşmazlığının
} 
birlikte kaldırılan karara bağlı olarak ortaya çıkan sonuçlar da kendiliğinden ortadan kalkmaktadır.

UM, uyuşmazlığın çözümü için kararları yeterli görmezse işin esasıyla ilgili yeni bir karar verir. Mahkeme bu kararı verirken önceki kararlarla ve tarafların talepleriyle bağlı değildir ${ }^{98}$. Kararda hangi gerekçelerle böyle bir sonuca varıldığı ve uyuşmazlığa konu olayın ne suretle çözüleceğine ayrıntılı olarak yer veriliir ${ }^{99}$.

Mahkeme, verilen kararların isabetsiz olduğunu ve uyuşmazlığın çözümünü sağlamayacağını düşünmesi durumunda her iki kararın da kaldırılmasına karar verir $^{100}$. Yani Mahkeme öncelikle yerel mahkemelerce verilen kararların yerinde olup olmadığını denetler ${ }^{101}$.

Benzer şekilde, verilen kararların sonuç olarak doğru olmalarına rağmen, uyuşmazlığın çözümü için yeterli olmamaları halinde, örneğin kararlardan birinin uyuşmazlığın bir kısmına, diğerinin de başka bir kısmına ilişkin olması ve birinde yer verilen hususlara diğerinde yer verilmemesi nedeniyle uyuşmazlığın çözümünü tam sağlayamamaları halinde de her iki kararın kaldırılmasına karar verir. UM, idari para cezası, ek sigorta primi, gecikme zammı ve faiz tutarına ilişkin bir uyuşmazlıkla ilgili verdiği kararında, olaya adli yargı mahkemesinin kararının uygulanması hâlinde idare mahkemesince hükme bağlanan "idari para cezastyla" ilgili uyuşmazlığın çözüme kavuşturulamayacağını, idare mahkemesi kararının olaya uygulanması hâlinde de "ek sigorta primi, gecikme zammı ve faiz tutarı" ile ilgili uyuşmazlığın çözüme kavuşturulamayacağını belirterek her iki kararı kaldırmış ve hem idari

giderilmesine karar verilmesi gerekmektedir." UM HB'nün 01.7.2013 K.T., 2011/120 E., 2013/1057 K. sayılı kararı; Benzer kararlar için bkz.; UM HB'nün 13.10.2014 K.T., 2013/1607 E., 2014/887 K. say1l1; 03.3.2014 K.T., 2012/164 E., 2014/143 K. say11;; 30.12.2013 K.T., 2012/328 E., 2013/1752 K. sayılı kararları; DURAN, s. 155; YEŞIL, s. 295; TERCAN, Esas Hakkında, s. 798.

${ }^{98}$ Uyuşmazlık Mahkemesi'nin dosyanın esasına girerek karar verdiği hüküm uyuşmazlığ dosyaları için bkz. UM HB'nün 28.9.2015 K.T., 2014/783 E., 2015/563 K. sayıl1; 13.10.2014 K.T., 2014/18 E., 2014/888 K. say111; 05.5.2014 K.T., 2013/665 E., 2014/501

K. say11; 01.4.2014 K.T., 2013/1148 E., 2014/314 K. say1l1 ve 28.9.2015 K.T., 2014/783 E., 2015/563 K. sayılı kararları.

${ }^{99}$ UM HB'nün 28.9.2015 K.T., 2014/783 E., 2015/563 K. sayıl1 karar1.

${ }^{100}$ UM'nin 08.12.1973 K.T., 1969/509 E., 1973/62 K. say1lı kararı; 06.3.1974 tarihli ve 14819 sayıl1 Resmi Gazete.

${ }^{101}$ YEŞİL, s. 294; TERCAN, Esas Hakkında, s. 798-799. 
para cezası hem de ek sigorta primi, gecikme zammı ve faiz tutarıla ilgili uyuşmazlıkların çözümü sağlayacak şekilde yeni bir karar vermiştir ${ }^{102}$.

Yine verilen kararlardan birinin isabetsiz, diğerinin isabetli olması ve isabetli kararın uyuşmazlığın çözümünü tam olarak sağlayamaması, yani yetersiz olması durumunda da her iki kararın kaldırılmasına karar verir ${ }^{103}$.

Son olarak, kararlardan birinin görevsiz, diğerinin görevli mahkemece verilmesi ve görevsiz mahkemece verilen kararın isabetli olmasına rağmen görevli mahkemece verilen kararın isabetsiz olması durumunda UM, verilen kararlardan birisi isabetli olsa da görevli mahkeme tarafindan verilememesi nedeniyle her ikisinin de kaldırılmasına karar vererek, kendisi işin esasıyla ilgili yeni bir karar verir ${ }^{104}$.

\section{bb. Ceza Davalarıyla İlgili Hüküm Uyuşmazlıklarının Çözüm Usulü}

UMK'nun 25. maddesinin 2. fikrasında: “Ceza alanındaki hüküm uyuşmazlıklarında Uyuşmazlık Mahkemesi, ...esasa ilişkin bir karar vermeksizin sadece o davayı hangi ceza mahkemesinin görüp karara bağlaması gerektiğini belirtmek suretiyle anlaşmazllğı çözer." ifadesine yer verilmiştir. Madde metninden de anlaşılacağı üzere ceza dosyalarıyla ilgili hüküm uyuşmazlıklarının çözümünde UM, bu uyuşmazlıklarla ilgili esastan bir karar vermemektedir. Görev uyuşmazlıklarının çözümünde olduğu gibi o uyuşmazlığı çözecek ceza mahkemesini belirlemekte ve belirlenen görevli mahkeme tekrar yargılama yapıp yeni bir karar

\footnotetext{
${ }^{102}$ UM HB'nün 13.10.2014 K.T., 2014/18 E., 2014/888 K. sayılı kararı; TERCAN, Esas Hakkında, s. 804 vd. YEŞİL, s. 296 vd.

${ }^{103}$ UM HB'nün 28.9.2015 K.T., 2014/783 E., 2015/563 K. say1l karar1.

104 “...Adli yargl yerince verilen kararın sonucu hukuka uygunluk arz etse de mahkemelerin görevine ilişkin olarak yapılan açıklamalardan hareketle ...İ̧s Mahkemesi kararının kaldırılması gerektiği izahtan varestedir. ...Idare Mahkemesi kararını bozan ve davanın esastan reddine karar veren ...Bölge idare Mahkemesi davada görevli ise de belirtilen nedenlerle bu mahkemece verilen kararda hukuki isabet bulunmadiğından, bu kararın da kaldırılması gerekmektedir. Bu saptama uyarınca uyuşmazlığın esası hakkında hüküm tesisi yoluna gidilmesi ve davacl lehine eksik ödenen tedavi malzemesi bedeline hükmedilmesi gerekmektedir." UM HB'nün 05.5.2014 K.T., 2013/665 E., 2014/501 K. sayıl1 karar1; Benzer karar için bkz., UM HB'nün 01.4.2014 K.T., 2013/1148 E., 2014/314 K. sayılı kararı; TERCAN, Esas Hakkında, s. 804 vd.; YEŞİL, s. 301 vd.
} 
vermektedir $^{105}$. Yani UM, doğru kabul ettiği bir kararın olaya uygulanmasına veya kararları yanlış bulsa da her ikisini kaldırıp esastan karar vermeye yetkili değildir ${ }^{106}$. Ceza uyuşmazlıklarının çözümüyle ilgili UMK'da yer alan düzenleme bu anlamda hüküm uyuşmazlığının varlık nedeniyle bağdaşmamakta ve usul ekonomisine de uymamaktadır. Zira UM tarafindan görevli kabul edilen mahkeme aynı dosyayla ilgili ikinci kez yargılama yapmak zorunda kalmaktadır. Bu nedenle UMK'nun 25. maddesinin 2. fikrasının değiştirilmesinde ve ceza dosyalarının çözümünde de hukuk dosyalarının çözümüne benzer hükümlere yer verilmesinde fayda olacağ 1 söylenebilir.

\section{Uyuşmazlık Mahkemesi Kararından Sonra Yapılacak İşlemler}

UM tarafindan verilen karar ilk derece mahkemelerine hemen bildirilir. UMK'nun 28. maddesinin 2. fikrası gereğince verilen kararlar sadece dosyanın taraflarını bağlar ${ }^{107}$. Hukuk davalarında kararlardan birinin kaldırılmasına ve diğerinin uygulanmasına karar verildiği durumlarda, bu karar UM tarafindan verilmiş yeni bir karar değildir ve uygulanmasına işaret edilen kararın önündeki engellerin kaldırılmasını ifade eder. Esastan verilen karar ise yeni bir karardır ve UMK'nun 29. maddesi gereğince verildiği anda $\operatorname{kesindir}^{108}$.

UM'nin kararının ilk derece mahkemesine ulaşmasından sonra, eğer kararlardan birinin kaldırılıp, diğerinin uygulanmasına karar verilmişse, kararı kaldırılan mahkeme karar defterine bu durumu şerh düşer. UM'nin her iki kararı kaldırıp dosyanın esası hakkında yeni bir karar vermesi halinde ise, kararları kaldırılan mahkemeler karar defterlerine bu hususu şerh düşerler.

Ceza dosyalarında her iki karar da kaldırıldığından mahkemeler bu durumu karar defterine şerh düşerler. Ayrıca yargılama yapmasına karar verilen mahkeme, şerh te UM'nin kararına dayanarak yeniden yargılama yapacağını da belirtir ${ }^{109}$.

\footnotetext{
${ }^{105}$ UM CB'nün 11.4.1983 K.T., 1983/47 E., 1983/149 K. sayılı karar1; UM CB’nün 27.6.1983 K.T., 1983/60 E., 1983/417 K. sayılı kararı; TERCAN, Hüküm Uyuşmazlığı, s. 556; DİNÇ, s. 20-21; YEŞİL, s. 307.

${ }^{106}$ UM CB'nün 22.12.1995 K.T., 1995/31 E., 1995/35 K. sayıl1 karar1.

${ }^{107}$ UM HB'nün 09.4.2012 K.T., 2011/66 E., 2012/61 K. say1lı karar1.

${ }^{108}$ KURU, s. 777; TERCAN, Esas Hakkında, s. 823; YEŞILI, s. 308; TERCAN, Hüküm Uyuşmazlı̆ $\breve{g}_{l}$, s. 205.

${ }^{109}$ TERCAN, Esas Hakkında, s. 843.
} 


\section{Bireysel Başvuruda Başvuru Yollarının Tüketilmesi Kavramı ve Anayasa Mahkemesi'nin Kararı Işığında Hüküm Uyuşmazlığının Tüketilmesi Gereken Bir Yol Olup Olmadiğı}

A. Genel Olarak

7/5/2010 tarihli ve 5982 sayılı Türkiye Cumhuriyeti Anayasası'nın Bazı Maddelerinde Değişiklik Yapılması Hakkında Kanun'un 12 Eylül 2010 tarihinde yapılan referandumla kabulünden sonra kişilere Anayasa Mahkemesi'ne bireysel başvuruda bulunma hakkı tanınmıştır ${ }^{110}$. Konunun düzenlendiği Anayasa'nın 148. maddesinin 3. fikrasında; "Herkes, Anayasada güvence altına alınmıș temel hak ve özgürlüklerinden, Avrupa Insan Haklart Sözleşmesi kapsamındaki herhangi birinin kamu gücü tarafindan, ihlâl edildiği iddiastyla Anayasa Mahkemesine başvurabilir. Başvuruda bulunabilmek için olağan kanun yollarının tüketilmiş olması şarttır." ifadesine yer verilmiştir.

Bireysel başvuru kapsamına giren hususlar da 6216 sayılı Anayasa Mahkemesi'nin Kuruluşu ve Yargılama Usulleri Hakkında Kanun'un ${ }^{111}$ 45. maddesinde düzenlenmiştir. Madde de: "Herkes, Anayasa'da güvence altına alınmış temel hak ve özgürlüklerden Avrupa İnsan Hakları Sözleşmesi ve buna ek Türkiye'nin taraf olduğu protokoller kapsamındaki herhangi birinin kamu gücü tarafindan ihlâl edildiği iddiasıyla Anayasa Mahkemesine başvurabilir." denilmiştir ${ }^{12}$. Madde metninde anlaşılacağ 1 üzere 6216 sayılı Yasa ile Anayasa'daki düzenleme genişletilmiş ve Avrupa İnsan Hakları Sözleşmesi (AİHS) kapsamında yer alan temel hak ve hürriyetlerle birlikte, ülkemizin taraf olduğu ek protokollerde güvence altına alınan temel hak ve hürriyetlerde bireysel başvuruya dâhil edilmiş ve başvurunun kapsamı genişletilmiştir ${ }^{113}$.

Anayasa'nın 148 ve 6216 sayılı Kanun'un 45 ila 47. maddeleri birlikte değerlendirildiğinde bireysel başvuruda bulunabilme şartları şöyle

\footnotetext{
${ }^{110}$ EKİNCİ, Hüseyin/SAĞLAM, Musa, Sorularla Anayasa Mahkemesi’ne Bireysel Başvuru, Anayasa Mahkemesi Yayınları, Ankara, 2014, s. 1.

111 03.4.2011 tarihli ve 27894 sayll Resmi Gazete.

${ }^{112}$ ÜNAL, Recep, Bireysel Başvuru Çerçevesinde İfade Özgürlüğ̈̈, Yayımlanmamış Doktora Tezi, Kırıkkale, 2014, s. 30; EKINCİ/SAĞLAM, s. 6.

${ }^{113}$ ATASOY, Hakan, Anayasa Mahkemesine Bireysel Başvuruda Kabul Edilebilirlik Koşulları, Adalet Yayınevi, Ankara, 2015, s. 201; DUYSAK FIDAN, Seda, Anayasa Yargısında Bireysel Başvuru Yolu ve Türkiye'de Gelişimi, Yayımlanmamış Yüksek Lisans Tezi, Ankara, 2013, s. 40-41.
} 
sıralanabilir: Kamu gücü kullanılmak suretiyle kişilerin bireysel başvuruya konu hak ve özgürlüklerinin ihlâl edilmiş olmasi ${ }^{114}$, başvuruya konu eylem ya da işlem sebebiyle bireyin güncel ve şahsi bir hakkının doğrudan etkilenmesi ${ }^{115}$, öngörülmüş olan idari ve yargisal bütün başvuru yollarının başvurudan önce tüketilmesi ${ }^{116}$, başvurunun, başvuru yollarının tüketildiği ya da öngörülmüss bir başvuru yolunun bulunmaması halinde ihlâlin öğrenildiği tarihten itibaren otuz gün içinde yapılmas ${ }^{117}$, yapılan başvuruyla ilgili Anayasa Mahkemesi'nin daha önce bir karar vermemiş olması, başvurucu tarafından başvuru hakkının açıkça kötüye kullanılmamış olmas1 ${ }^{118}$, başvurunun Yasa'da öngörülen haklarla ilgili olmas $1^{119}$, başvurucunun uğradığı zararın önemli bir zarar olması ve başvurunun açıkça dayanaktan yoksun olmamasıdır.

Bireysel başvuru şartlarına değindikten sonra UM kararlarına karş1 bireysel başvuru yoluna gidilip gidilemeyeceği hususuna da değinilmesinde fayda vardır. Burada ilk olarak 6216 sayılı Kanun'un bireysel başvuruya konu edilemeyecek hususların yer aldığı 45 . maddesinin 3. fikrasina bakmak gerekir. Anılan maddede: "Yasama işlemleri ile düzenleyici idari işlemler aleyhine doğrudan bireysel başvuru yapılamayacağı gibi Anayasa Mahkemesi kararları ile Anayasa'nın yargl denetimi dışında biraktlğı işlemler de bireysel başvurunun konusu olamaz. " hükmüne yer verilmiştir.

Maddede, UM kararları aleyhine bireysel başvuru yapılmasına engel bir hüküm bulunmamaktadır. Her ne kadar Mahkemenin verdiği kararlar kesin olsa da, bu kesinlik bireysel başvuruya engel değildir ve bu kararların kesinleşen diğer mahkeme kararlarından farkı yoktur. Kısacası, verilmiş olan UM kararı nedeniyle hakkının ihlâl edildiğini düşünen

\footnotetext{
${ }^{114}$ SAĞLAM, Musa/EKİNCI, Hüseyin, 66 Soruda Anayasa Mahkemesine Bireysel Başvuru, Şen Matbaas1, Ankara, 2012, s. 13; DUYSAK FIDAN, s. 46.

${ }^{115}$ EKINCİ, Hüseyin "Kabul Edilebilirlik Kriterleri”, Bireysel Başvuru, İnceleme Usulü ve Kabul Edilebilirlik Kriterleri, (Editör: Musa SAĞLAM), Şen Matbaa, Ankara, 2013, s. 124-125, (“Kriterler"); ÜNAL, s. 25; EKİNCİ/SAĞLAM, s. 44; DUYSAK FIDAN, s. 72.

${ }^{116}$ Anayasa Mahkemesi Birinci Bölüm, Başvuru No: 2012/363, Karar Tarihi: 05.03.2013, (Çalışmada yer verilen Anayasa Mahkemesi kararları http://www.anayasa.gov.tr/icsayfalar/kararlar/kbb.html adresinden alınmıştır. Sonraki alıntılarda ayrıca kaynak belirtilmeyecektir).

${ }^{117}$ SAĞLAM/EKİNCI், s. 25 ve 79; DUYSAK FIDAN, s.79.

${ }^{118}$ EKINCI, Kriterler, s. 154,159; DUYSAK FIDAN, s. 101.

${ }^{119}$ DUYSAK FİDAN, s. 117; SAĞLAM/EKİNCİ, s. 14.
} 
gerçek ya da tüzel kişiler, diğer şartların varlığı halinde Anayasa Mahkemesi'ne bireysel başvuruda bulunabilirler ${ }^{120}$.

\section{B. Başvuru Yollarının Tüketilmesi Kavramı}

Anayasa'nın 148. maddesinin 3. fikrasında, bireysel başvuruda bulunabilmek için öncelikle "olağan kanun yolları" nın tüketilmesi gerektiği düzenlenmiştir ${ }^{121}$. Benzer düzenlemeye 6216 sayılı Kanun'un 45. maddesinin (2) numaralı fikrasında da yer verilmiş ve ihlâle neden olduğu ileri sürülen işlem, eylem ya da ihmâl için kanunda öngörülmüş "idari ve yargisal başvuru yollarının" tümünün bireysel başvuru yapılmadan önce tüketilmesi gerektiği ${ }^{122}$ ve bu yollar tüketilmeden yapılan başvuruların reddedileceği hükme bağlanmıştır ${ }^{123}$. Bireysel başvuruda idari ve yargısal yolların tüketildiğinin başvurucu tarafından ispat edilmesi gerekir ve başvuru yollarının tüketilip tüketilmediğini Anayasa Mahkemesi resen gözetir ${ }^{124}$.

$\mathrm{Bu}$ kuralın getirilme nedeni, hak ihlallerinin Anayasa Mahkemesi'nden önce idari ve yargısal makamlar tarafindan giderilmesini sağlamaktır. $\mathrm{Bu}$ durum, bireysel başvurunun ikincil nitelikte bir yol olmasından kaynaklanır ${ }^{125}$. Yine bireysel başvuruda bulunulabilmesi için

${ }^{120}$ YEŞİL, s. 346.

${ }^{121}$ EFE, Metin, Anayasa Mahkemesi Uygulamaları Kapsamında Bireysel Başvuruda Kabul Edilebilirlik Şartları, Seçkin Yayıncılık, Ankara, Mayıs 2016, s. 250; ATASOY, s. 197; GÖZTEPE, Ece, “Türkiye'de Anayasa Mahkemesi'ne Bireysel Başvuru Hakkının (Anayasa Şikâyeti) 6216 Sayılı Kanun Kapsamında Değerlendirilmesi”, Türkiye Barolar Birliği Dergisi, S. 95, Ankara, 2011, s. 14.

122 “...Başvuru yolları, başvurucunun şikâyetleri açısından makul bir başarı şansı sunabilecek ve bir çözüm sağlayabilecek nitelikte, kullanılabilir ve etkili başvuru yollarını ifade etmektedir." Anayasa Mahkemesi İkinci Bölüm, Bireysel Başvuru No: 2013/6359, Karar Tarihi: 12.10.2014.

${ }^{123}$ Anayasa Mahkemesi Birinci Bölüm, Bireysel Başvuru No: 2013/1205, Karar Tarihi: 17.9.2013.

${ }^{124}$ EFE, s. 252; ATASOY, s. 197.

${ }^{125}$ Anayasa Mahkemesi İkinci Bölüm, Bireysel Başvuru No: 2012/946, Karar Tarihi: 26.3.2013; Kabul Edilebilirlik Kriterleri, (Editör: Musa SAĞLAM/Hasan Tuna GÖKSU), Anayasa Mahkemesi Yayınları, Ankara, 2014, s. 101; ŞEN, Murat, "Başvuru Yollarının Tüketilmesi Kuralı", Anayasa Mahkemesine Bireysel Başvuru Usulü ve Kabul Edilebilirlik Kriterleri, (Editörler: Hüseyin TURAN/Recep KAPLAN), Anayasa Mahkemesi Yayınları, Ankara, 2015, s. 85; EKİNCİ, Hüseyin, "Anayasa Mahkemesine Bireysel Başvurularda Bir Kabul Edilebilirlik Koşulu Olarak "Başvuru Yollarının Tüketilmesi" Sorunu", Türkiye Adalet Akademisi Dergisi, Y: 3, S. 11, Ankara, 2012, s. 17-18, ("Tüketilmesi"); ER, Selami, "Bireysel Başvuru İncelemesinde 
idari ve yargı mercileri tarafından konuya ilişkin verilmiş olan kararın kesinleşmesi gerekir ki, bu durum da bireysel başvurunun tamamlayıcı niteliğinin bir sonucudur. Yani Anayasa Mahkemesi, bireysel başvuruda mahkemelerin ve idari mercilerin hak ihlalini gideremedikleri durumlarda devreye girmektedir ${ }^{126}$.

Anayasa Mahkemesi uygulamasında, bireysel başvuruda bulunulabilmesi için başvuruya konu kararla ilgili öngörülmüş olağan kanun yollarının bulunması durumunda öncelikle bu yollara müracaat edilmelidir. Yani temyiz, itiraz ve istinaf kanun yolları tüketilmesi gereken başvuru yollarıdır ${ }^{127}$. Ancak olağanüstü kanun yolları, başvurucunun doğrudan ulaşamaması ve bu başvuru yollarına müracaatın başka bir makamın takdirine bağlı olması nedeniyle ${ }^{128}$ "etkili" ve "ulaşılabilir" bir yol olarak kabul edilmemektedir ${ }^{129}$. Anayasa

Mülkiyet Hakkı", İnsan Onuru İçin Anayasa Mahkemesinde 25 Yıl, Haşim KILIÇ’a Armağan, (Editörler: Ali Rıza ÇOBAN/Serdar GÜLENER/Musa SAĞLAM/Hüseyin EKİNCI), C. 2, Ankara, 2015, s. 1451; EFE, s. 253; EKİNCI/SAĞLAM, s. 46-47.

${ }^{126}$ ÖZBEY, Özcan, Türk Hukukunda Anayasa Mahkemesine Bireysel Başvuru Hakkı, Adalet Yayınevi, Genişletilmiş 2. Baskı, Ankara, 2013, s. 285, ("Bireysel Başvuru”); TÜRMEN, Rıza, "İnsan Hakları Sözleşmesi Sisteminde İç Hukuk Yollarının Tüketilmesi”, İstanbul Üniversitesi Hukuk Fakültesi Dergisi, Prof. Dr. Sahir ERMAN'a Armağan, No: 8, İstanbul, 1999, s. 777; ATASOY, s. 199; EFE, s. 264.

127 "...Ceza muhakemesinde tüketilmesi gereken son başvuru yolu kural olarak temyizdir”, Anayasa Mahkemesi Birinci Bölüm, Bireysel Başvuru No: 2013/1999, Karar Tarihi: 09.01.2014; Kabul Edilebilirlik Kriterleri, s. 112-113; EFE, s. 269; ATASOY, s. 202; ŞEN, s. $97 \mathrm{vd}$.

“...Ceza yargılamasında tüketilmesi gereken son başvuru yolu temyiz aşaması olup temyiz incelemesinden geçen kararlara karşı itiraz yolu, 5271 sayıl Kanun'un 308. maddesi gereğince Yargitay cumhuriyet başsavcısına tanınmıştır. Dolayısıyla başvurucunun itiraz yoluna gidilmesi istemi, sadece Yargitay cumhuriyet başsavcisinın takdirini harekete geçirmeye yönelik bir taleptir. Bu kapsamda yapılan başvurular bireysel başvuru öncesinde tüketilmesi gereken bir yol olarak kabul edilmediğinden, bu yola gidilmesinin bireysel başvuru süresi üzerinde herhangi bir etkisi olmayacaktır." Anayasa Mahkemesi İkinci Bölüm, Bireysel Başvuru No: 2013/2001, Karar Tarihi: 16.5.2013.

129 “...5271 sayll Kanun'un 309. ve 310. maddeleri uyarinca kanun yararina bozma; hâkimler ve mahkemeler tarafindan verilen ve istinaf veya temyiz incelemesinden geçmeksizin kesinleşen kararlar için öngörülen ve bu kararların Yargıtayca denetlenmesini sağlayan bir kanun yoludur. Amacı kesinleşen kararlardaki hukuka aykırılıkları gidermek ve kanunların ülke içinde eşit bir şekilde uygulanmasını sağlamak olan kanun yararına bozma, kesin kararlara karşı başvurulan bir yol olduğundan, olağanüstü bir kanun yoludur. Öte yandan kanun yararına bozma, kişiler için doğrudan ulaşılabilir bir yol olmayıp olağanüstü bir kanun yolu niteliği taşımakla, tüketilmesi 
Mahkemesi de -temyiz incelemesinden geçen bir karara karş1- CMK'nun 308. maddesi gereğince yapılan "itiraz" başvurusunu, bu başvuruyu yalnızca Yargitay Cumhuriyet Başsavcısının yapabilmesi, talepte bulunanların istemlerinin sadece başsavcının harekete geçirilmesine yönelik olması nedeniyle tüketilmesi gereken bir yol olarak kabul etmemiştir ${ }^{130}$.

Bir kanun yolunun olağan kabul edilmesi için sadece kanunlarda olağan kanun yolları arasında düzenlenmesi yeterli değildir. Ayrıca bu kanun yolunun kişiler açısından belirgin olması, dolambaçlı olmaması ve başvuru yolunun tüketilmesi halinde meydana gelen hak kayılarını gidermede makul bir başarı şansı sunması gerekir $^{131}$.

Bir kanun yoluna başvuru konusunda kişilere seçim hakk1 verilmişse o kanun yolunun zorunlu olduğundan söz edilemez ve bu yol tüketilmeden de bireysel başvuru yapılabilir ${ }^{132}$.

Başvuruda bulunan kişi kendi hatası ya da ihmali yüzünden kanunda öngörülen olağan kanun yoluna başvurmadan bireysel başvuruda bulunursa, başvurusu reddedilir. Çünkü başvurucunun bu konuda özen yükümlülüğ̈̈ vardır ve bu yükümlülüğe uymak zorundadır. Ancak hak ihlaline yönelik herhangi bir kanun yolu öngörülmemişse başvuru yolunun tüketilmesi aranmaz. Bu halde bireysel başvuru süresi, başvuruya konu olayın veya ihlalin meydana geldiği veya işlemin ihdas edildiği tarihten başlar ${ }^{133}$.

Olağan başvuru yollarının tüketilmesi katı bir şekilde yorumlamamalı, her olayın kendine özgü şartları dikkate alınarak değerlendirilmelidir. Çünkü kuralın katı yorumlanması halinde bireysel başvurunun amacıyla bağdaşmayan neticeler ortaya çıkabilir. Zira bireysel başvurunun amacı varlığı iddia edilen hak ihlallerinin tespiti ve

gereken bir yol değildir.” Anayasa Mahkemesi Birinci Bölüm, Bireysel Başvuru No: 2012/644, Karar Tarihi: 05.3.2012.

130 Anayasa Mahkemesi İkinci Bölüm, Bireysel Başvuru No: 2013/1610, Karar Tarihi: 13.6.2013.

${ }^{131}$ Anayasa Mahkemesi Birinci Bölüm, Bireysel Başvuru No: 2012/1158, Karar Tarihi: 21.11.2013; Benzer yöndeki karar için bkz. Anayasa Mahkemesi İkinci Bölüm, Bireysel Başvuru No: 2012/338, Karar Tarihi: 02.7.2013; EKİNCİ, Tüketilmesi, s. 17; ŞEN, s. 99; EFE, s. 269; EKİNCI/SAĞLAM, s. 48-49.

${ }^{132}$ EFE, s. 265.

${ }^{133}$ ATASOY, s. 204; EFE, s. 269; ÖZBEY, s. 260; 
giderilmesi, dolayısıyla hakların etkin bir şekilde korunmasıdır ${ }^{134}$. Bu nedenle, bireysel başvuru yapılmadan önce tüketilmesi gereken kanun yollarının ihlal iddialarını tespit ve gidermede "etkili" ve "mevcut" olması gerekir. Dolayısıyla kanunda olağan bir kanun yolu öngörülse dahi, öngörülen kanun yolu fiilen uygulanmiyor veya etkili bir yol olarak değerlendirilmiyorsa başvurucunun bu yolu tüketmesi beklenmez. Ancak durumun yargısal içtihatlar ya da yasa hükümleriyle ortaya konulması gerekir $^{135}$.

Bazen hak ihlâlinin giderilmesi amaciyla birden çok ve etkili kanun yolu öngörülmüş olabilir. Böyle durumlarda başvurucunun etkili yolların tamamını tüketmesi gerekmez ve hangi kanun yoluna müracaat edeceğine karar verme yetkisi başvurucuya aittir. Başvurucunun, başvuru yollarından sadece birini tüketmek suretiyle yaptı̆̆ başvuru, diğer etkili başvuru yollarına müracaat etmediği gerekçesiyle reddedilmez ${ }^{136}$. Konuyla ilgili Avrupa İnsan Hakları Mahkemesi (AİHM) içtihatları da aynı yöndedir ve Mahkeme bir başvuruda; hukuk yolunun ceza yolundan daha etkili olduğuna karar verilemeyeceğini ve başvurucunun iki yoldan biri olan hukuk yolunu, ceza yoluna tercih etmesinin başvuru yollarının tüketilmesi açısından yeterli olduğunu hükme bağlamıştır ${ }^{337}$.

Bireysel başvuru yapılmadan evvel etkili ve sonuç almaya yönelik bir kanun yoluna başvurulması halinde, bireysel başvuru için bu başvurunun sonucu beklenmelidir ${ }^{138}$.

Kanun yolunun tüketilmesi, başvurunun öngörülen usul kurallarına uygun yapılmasına bağlıdır. Örneğin, 5271 sayılı Kanun'a ${ }^{139}$ göre temyiz süresi yedi gündür. Başvurucunun sekizinci günde temyiz isteminde

\footnotetext{
${ }^{134}$ Anayasa Mahkemesi Birinci Bölüm, Bireysel Başvuru No: 2013/1582, Karar Tarihi: 7.11.2013.

${ }^{135}$ ÖZBEY, Özcan, "Anayasa Mahkemesine Bireysel Başvurularda Kabul Edilmezlik Nedenleri", Türkiye'de Anayasa Mahkemesine Bireysel Başvuru (Anayasa Şikâyeti), (Editör: Sevtap YOKUŞ), Seçkin Yayıncılık, Ocak 2014, Ankara, s. 200, (“Anayasa Şikayeti"); EFE, s. 268; ATASOY, s. 206 vd.

${ }^{136}$ EKINCI, Tüketilmesi, s. 5; ÖZBEY, Bireysel Başvuru, s. 27; EFE, s. 265-266.

${ }^{137}$ AİHM'nin, Ramazan Yıldırım/Türkiye Kararı, Başvuru No: 4300/05, Karar Tarihi: 06.01.2009; AİHM'nin, Karako/Macaristan Kararı, Başvuru No: 39311/05, Karar Tarihi: 28.4.2009.

${ }^{138}$ Anayasa Mahkemesi İkinci Bölüm, Bireysel Başvuru No: 2012/26, Karar Tarihi: 26.3.2013.

${ }^{139}$ 17.12.2004 tarihli ve 25673 say1l Resmi Gazete.
} 
bulunması durumunda, başvurusu reddedilir. Yani sadece öngörülen yasa yoluna başvuru yeterli olmayıp, başvurunun usulüne uygun olarak da yapilması gerekir $^{140}$.

Başvurucu, kendisiyle ilgili olan fakirlik, hastalık, bilgisizlik, yaşlılık gibi nedenlerden ötürü başvuru yollarını tüketmekten kaçınamaz ve bu sebeplere dayanarak mazeret beyanında bulunamaz ${ }^{141}$.

Hak ihlâline ilişkin iddiaların idari ve yargısal başvuru yolu aşamasında ileri sürülmesi gerekir. Bu aşamalarda dile getirilmeyen hak ihlalleriyle ilgili Anayasa Mahkemesi'ne başvuru yapılamaz ${ }^{142}$. Yine idari ve yargısal başvuru yollarında sunulmamış olan bilgi ve belgeler de bireysel başvuruda sunulamaz. Zira bireysel başvurunun ikincilliği ilkesi gereği temel hak ve özgürlüklerin ihlâliyle ilgili bilgi ve belgelerin öncelikle başvuru yollarında sunulması ve bu makamlarda şikâyetin çözüme kavuşturulması beklenir ${ }^{143}$. Benzer şekilde, bireysel başvuruya konu hak ihlâllerinin AHİS ve Anayasa'nın hangi maddelerine ilişkin olduğunu belirtilmek zorunlu olmayıp, ihlâl iddialarının özü itibariyle belirtilmesi yeterlidir ${ }^{144}$.

C. Hüküm Uyuşmazlığının Bireysel Başvuru Açısından Tüketilmesi Gereken Bir Yol Olup Olmadığı ve Olağan Kanun Yolu Kapsamında Değerlendirilip Değerlendirilemeyeceği

Başvuru yollarının tüketilmesi kavramıyla ilgili açıklamalar 1şığında, hüküm uyuşmazlığının çözümü amacıyla UM'ne yapılan başvurunun tüketilmesi gereken, etkili ve ulaşılabilir bir başvuru yolu olup olmadığının incelenmesi ve bunun için de hüküm uyuşmazlığının olağan mı yoksa olağanüstü bir başvuru yolu mu olduğunun açıklığa kavuşturulması gerekir. Zira UM'ne yapılacak başvurunun, tüketilmesi gereken bir yol olup olmadığı öncelikle buna bağlıdır.

Bize göre UM, dört yarg1 kolundan bağımsız da olsa görevi gereği ülkemizde var olan yarg1 ayrılı̆̆ sisteminden kaynaklı sorunları

\footnotetext{
${ }^{140}$ AİHM'nin Azinas/Kıbrıs Kararı, Başvuru No: 56679/00, Karar Tarihi: 28.4.2004; EFE, s. 260; Kabul Edilebilirlik Kriterleri, s. 108.

${ }^{141}$ EFE, s. 261; ATASOY, s. 234; ÖZBEY, Bireysel Başvuru, s. 26-27.

${ }^{142}$ ÜNAL, s. 11; EFE, s. 261.

${ }^{143}$ Anayasa Mahkemesi İkinci Bölüm, Bireysel Başvuru No: 2012/946, Karar Tarihi: 26.3.2013.

${ }^{144}$ EKİNCI, Tüketilmesi, s. 6; EFE, s. 261-262.
} 
çözmektedir. Zira bu sistemin geçerli olduğu ülkelerde görev ve hüküm uyuşmazlıklarının çıkması kaçınılmazdır. Her ne kadar hüküm uyuşmazlığı şartları ve oluşumu değerlendirildiğinde olağanüstü bir yol gibi görünse ve olağanüstü kanun yollarına benzese de, aslında durum böyle değildir. Zira yargı kollarının usul kanunlarında düzenlenen olağanüstü kanun yollarına, derecattan geçen ve uyuşmazlığın çözülemediği durumlarda son çare olarak başvurulur. Yani usulüne uygun verilip kesinleşen kararlarla ilgili o yargı kolu açısından bir sorun bulunmamaktadır.

Hüküm uyuşmazlığı açısından ise asıl sorun bu aşamada başlamakta ve farklı yargı kollarına dâhil mahkemelerce aynı konuda verilen ve kesinleşen çelişkili kararlar nedeniyle hakkın yerine getirilmesi imkânsız hale gelmektedir. Yani bu uyuşmazlıkta -olağanüstü kanun yollarında olduğu gibi- yargı kollarının iç işleyişinden değil, yarg1 sisteminin işleyişinden kaynaklı bir sorun bulunmaktadır ${ }^{145}$.

Yarg1 birliği sisteminin geçerli olduğu ülkelerde temyiz merciinin incelemesinden geçen kararlarla ilgili böyle bir durumla karşılaşılması çok zordur. Çünkü bu sistemde, temyiz incelemesi tek olan yüksek mahkeme tarafindan yapılır. Ancak temyiz incelemesinden geçmeyen ya da sadece birinin bu incelemeden geçtiği kararlar arasında hüküm uyuşmazlığ çıkabilir ve bu uyuşmazlık yine yüksek mahkeme tarafından çözülür.

Yarg1 ayrıllğı sisteminin olduğu ülkelerde ise, her yarg1 kolunun usul kanununa göre kesinleșen mahkeme kararları icrai nitelikte olduğundan, aynı konuda farklı yargı kollarına dâhil mahkemelerce karar verilmesi ve bu kararların bir biriyle çelişmesi mümkündür. Bu sebeple de bu ülkelerde adeta hakem görevi yapacak ve kesinleşmiş kararlardan dava konusu olaya uygulanacak olanı belirleyecek bir müesseseye ihtiyaç vardır ki, ülkemizde bu ihtiyacı UM gidermektedir. Nitekim AİHM'ne göre de, yarg1 ayrılığı sisteminin geçerli olduğu ülkelerde içtihat farklılıklarından kaynaklı hak kayıplarının önlenmesi adına içtihatları uyumlaştıracak mekanizmalara ihtiyaç vardır. Böyle bir mekanizma adil yargılanma hakkının gereklerinden birisidir ${ }^{146}$. Bu yönüyle $U M$, AİHM'nin belirttiği mekanizmaya karşıllk gelmektedir.

\footnotetext{
145 YEŞİL, s. 353.

${ }^{146}$ AİHM'nin Nejdet Şahin-Perihan Şahin/Türkiye Kararı, Başvuru No: 13279/05, Karar Tarihi: 20.10.2011.
} 
Hüküm uyuşmazlığı, yarg1 sisteminden kaynaklı ihtilafların çözümü ve siteminin olağan işleyişini sağlamak için öngörülen hukuksal bir yoldur ve usul yasalarında düzenlenen kanun yollarından farklı olduğu kabul edilmelidir. Ayrıca, Anayasa'nın 148. maddesindeki bireysel başvuru şartlarından olan olağan kanun yollarına başvuru ifadesi de mutlaka usul kanunlarındaki "yasa yollarıyla" sınırlı değerlendirilmemeli ve bunlar dışında, başka kanunlarda ${ }^{147}$ öngörülen başvuru yollarının da "yasa yolu" veya daha geniş anlamıla "kanunda öngörülmüş başvuru yolu” olarak değerlendirilmelidir. Kaldı ki 6216 Kanun'un 45. maddesinin 2. fikrası da düşünceyi destekler niteliktedir. Maddede, bireysel başvuru için kanunlarda öngörülen idari ve yargısal başvuru yollarının tüketilmesi yeterli kabul edilmiş ve olağan ya da olağanüstü kanun yolu ayrımı yapılmamıştır.

Yukarıdaki açıklamalar ışı̆̆ında hüküm uyuşmazlığına müracaat, başvuru yollarının tüketilmesi açısından zorunlu, Anayasa'nın 148. maddesinin 3. fikrası anlamında da olağan kanun yolu olarak değerlendirilmeli ve bu uyuşmazlığa ilişkin başvurunun, başka bir merciin onayına ihtiyaç duymadan dosyanın taraflarınca yapılabilmesi nedeniyle de etkin ve ulaşılabilir bir yol olduğu kabul edilmelidir.

\section{Anayasa Mahkemesi Kararı Işı̆̆ı̆ı Konunun Değerlendirilmesi}

UM tarafindan verilen kararlar aleyhine yapılmış bireysel başvuruların büyük çoğunluğu Mahkeme'nin görev uyuşmazlığ kapsamında verdiği kararlara ilişkindir ${ }^{148}$. Hüküm uyuşmazlığı kapsamında verilen kararlardan sadece biri aleyhine bireysel başvuruda bulunulmuş, fakat başvuruyla ilgili adil yargılanma hakkının ihlal edildiğine ilişkin iddiaların dayanaktan yoksun olması nedeniyle ihlal

${ }^{147}$ UMK'da görev ve hüküm uyuşmazlıklarının çözümü için öngörülmüş başvuru yolları gibi.

${ }_{148}$ Anaysa Mahkemesi'nin resmi Web sitesinden yapılan araştırma neticesinde UM'nin görev uyuşmazlığı kapsamında verdiği kararlar aleyhine yapılan başvurular olarak şunlar tespit edilmiştir: Anayasa Mahkemesi İkinci Bölüm, Bireysel Başvuru No: 2013/1586, Karar Tarihi: 18.9.2013; Anayasa Mahkemesi İkinci Bölüm, Bireysel Başvuru No: 2013/5718, Karar Tarihi: 20.3.2014; Anayasa Mahkemesi İkinci Bölüm, Bireysel Başvuru No: 2013/1793, Karar Tarihi: 18.9.2014; Anayasa Mahkemesi Birinci Bölüm, Bireysel Başvuru No: 2013/135, Karar Tarihi: 21.01.2015; Anayasa Mahkemesi İkinci Bölüm, Bireysel Başvuru No: 2013/9669, Karar Tarihi: 19.11.2015. 
kararı verilmemiştir ${ }^{149}$. Ayrıca, bu başvuruda Anayasa Mahkemesi, hüküm uyuşmazlı̆̆ının etkili ve tüketilmesi gereken bir başvuru yolu olup olmadığına değinmemiştir. Ancak Mahkeme, daha sonraki tarihli bir başvuruda kendisine yapılan başvurunun hüküm uyuşmazlığı niteliğinde olduğunu ve bu yola başvurulmadan kendisine müracaat edilemeyeceğini belirterek başvuruyu reddetmiştir. Çalışmanın bu kısmında, UM açısından çok önemli olduğu düşünülen ve hüküm uyuşmazlığını etkili bir başvuru yolu kabul eden Anayasa Mahkemesi İkinci Bölümü tarafindan 14.4.2016 tarihinde verilen 2013/8173 başvuru numaralı kararının değerlendirilmesine yer verilecektir.

\section{Başvuruya Konu Olay}

Başvuruya konu olayda; bir hastanede radyoloji teknisyeni olarak çalışan başvurucuya 2004 ile 2006 yılları arasında fazladan özel hizmet tazminatı ve yan ödeme yapıldığ 1 belirtilerek ödenen miktarın iadesi istenmiş, başvurucunun bu talebe itiraz etmesi üzerine Sağlık Bakanlığ paranın tahsili için sulh hukuk mahkemesine alacak davası açmış ve mahkeme davayı kabul ederek fazladan ödenen miktarın başvurucudan tahsiline karar vermiştir ${ }^{150}$.

Başvurucu da, fazladan ödendiği iddia edilen paranın iadesini içeren işlemin iptali için süresinde idare mahkemesine dava açmış, mahkeme davaya konu olan işlemin iptaline ve yapılan kesintinin başvurucuya (davaciya) ödenmesine karar vermiştir.

\section{Başvurucunun İddiaları}

Başvurucu; kendisine fazladan ödeme yapıldığı iddiasıyla iadesi istenen miktarla ilgili işleme karşı idare mahkemesine açtığı davanın lehine sonuçlandığını, ancak aleyhine sebepsiz zenginleşme iddiasıyla sulh hukuk mahkemesine açılan davanın da kabul edildiğini ve böylece taraf, sebep ve konuları aynı olan davalarda çelişkili kararların ortaya çıktığını belirtmiştir.

Başvurucu, konuyla ilgili Yargıtay ve Danıştay İçtihadı Birleştirme Kararları bulunduğunu, Yargıtay İçtihadı Birleştirme Kurulu'nun; yapılan fazla ödemenin özel bir süre öngörülmüssse bu sürede ya da iptal davası açılması söz konusuysa dava açma süresi sonuna kadar istenebileceğini,

${ }^{149}$ Anayasa Mahkemesi Birinci Bölüm, Bireysel Başvuru No: 2013/5051, Karar Tarihi: 16.12.2015.

${ }^{150}$ Anayasa Mahkemesi İkinci Bölüm, Bireysel Başvuru No: 2013/8173, Karar Tarihi: 14.4.2016. 
bu sürelerin geçmesinden sonra yapılan ödemenin artık geçerli bir ödeme olduğunu ve sebepsiz zenginleşme hükümlerine göre de geri istenemeyeceğini belirttiğini dile getirmiştir ${ }^{151}$.

Benzer şekilde, Danıştay İçtihadı Birleştirme Kurulu'nun da; yapılan haksız ödemenin altmış günlük dava açma süresi içinde ve bu süre geçtikten sonra ise yalnızca yokluk, açık hata, gerçek dışı beyan veya hile hâllerinde geri istenebileceğini belirttiğini dile getirmiştir ${ }^{152}$.

Başvurucu, dava konusu olayla ilgili Yargıtay İçtihadı Birleştirme Kurulu kararı bulunmasına rağmen sulh hukuk mahkemesi ve Yargitay'ın bu kararı dikkate almadıklarını ve sebepsiz zenginleşmenin varlığını kabul ederek aleyhine karar verdiklerini, olayda sebepsiz zenginleşme hükümleri uygulansa bile, fazladan yapılan ödemenin bir y1llık zamanaşımı süresi içinde geri istenebileceğini ancak bu sürenin de geçtiğini belirtmiştir.

Başvurucu ayrıca, kendisiyle aynı işi yapan başka bir radyoloji teknisyeni aleyhine fazladan yapıldığı iddia edilen ödemenin iadesi için başka bir sulh hukuk mahkemesine açılan davada, mahkemenin Danıştay içtihadı birleştirme kararına dayanıp idarenin talebini reddettiğini ve bu karar üzerine yapılan kesintinin o kişiye iade edildiğini belirtmiş ve aynı alacak için adli yargı mahkemesiyle idari yargı mahkemesinin farklı kararlar vermesinin hukuki güvenlik ve eşitlik ilkesine aykırı olduğunu ve böylece Anayasa'nın 2., 10. ve 36. maddelerinde düzenlenen hakların ihlal edildiğini ileri sürüp, yeniden yargılanma ve tazminata karar verilmesini talep etmiştir.

\section{Anayasa Mahkemesi'nin Konuya İlişkin Kararı}

Anayasa Mahkemesi, sulh hukuk mahkemesi ve idare mahkemesine açılan davaların konusunun, başvurucuya yapılan ödemenin niteliği ile bu ödemenin idare tarafindan geri istenilip istenilmeyeceği olduğunu ve bu iki kararın birbiriyle çeliştiğini belirtmiştir. Ayrıca daha önceki bir tarihte UM'nin, fazladan ödenen denetim tazminatıyla ilgili idare mahkemesi ve sulh hukuk mahkemesi kararları arasında oluşan çelişkinin hüküm uyuşmazlığı niteliğinde olduğunu belirterek başvuruyu esastan karara

\footnotetext{
${ }^{151}$ Yargıtay İçtihadı Birleştirme Kurulu'nun 27.01.1973 K.T., 1972/6 E., 1973/2 K. sayılı kararı.

${ }^{152}$ Danıştay İçtihadı Birleştirme Kurulu'nun 22.12.1973 K.T., 1968/8 E., 1973/14 K. sayılı karar1.
} 
bağladığını ${ }^{153}$ ve bu kararın bireysel başvuruya konu olayla aynı olduğunu dile getirmiştir.

Yüksek Mahkeme sonuç olarak; bireysel başvuruya konu mahkeme kararları arasındaki çelişkinin de hüküm uyuşmazlığı niteliğinde olduğunu, tarafların bir başvuru süresi olmadan hüküm uyuşmazlığının çözümü için UM'ne başvurabileceklerini, başvurucunun etkili bir çözüm yolu olan hüküm uyuşmazlığına başvurmadan bireysel başvuru yoluna müracaat edemeyeceğini belirtmiş ve başvuru yollarının tüketilmemesi nedeniyle başvurusunun kabul edilemez olduğunu hükme bağlamıştır ${ }^{154}$.

\section{Kararın Değerlendirilmesi}

Kararın bir husus dışında isabetli olduğu ve 6216 sayılı Kanun'un 45. maddesinin 2. fikrasında ifadesini bulan "kanunda öngörülmüş idari ve yargisal başvuru yollarının tamaminın bireysel başvuru yapılmadan önce tüketilmiş olması gerekir" hükmüne uygun olarak verildiği değerlendirilmektedir. Zira hüküm uyuşmazlığına başvuru, maddede belirtilen ve yapılması zorunlu olan başvuru yollarından biridir. Her ne kadar Anayasa'nın 148. maddesinin 3. fikrası gereğince, olağanüstü kanun yollarına başvurulmadan bireysel başvuru yapılabileceği ve bu bağlamda hüküm uyuşmazlığına başvurulmadan bireysel başvuruda bulunulabileceği söylenebilirse de, daha öncede ifade edildiği üzere, hüküm uyuşmazlığı yargı ayrılığı sisteminin bir sonucudur.

Uyuşmazlığa konu kararlar ilgili yargı kollarının usul kanunlarına uygun olarak verilmişlerdir. Ayrıca bu kararlarla ilgili olağanüstü kanun yollarına başvurulmasını gerektirecek bir durum da yoktur. Yani hüküm uyuşmazlığına konu kararlarla ilgili yargı kolları açısından bir sorun bulunmamakta ve sorun yargı sisteminin işleyiş̧inden kaynaklanmaktadır.

\footnotetext{
${ }^{153}$ Hüküm uyuşmazlığına konu bu olayda idare mahkemesi, idarenin fazla ödediği tutarın istenilmesine ilișkin ișlemin iptaline ve tahsil edilmiș tutarın davacıya geri ödenmesine; sulh hukuk mahkemesi ise aynı konuda sebepsiz zenginleşme hükümlerine göre fazladan ve yersiz ödenen miktarın davacıdan alınarak idareye ödenmesine karar vermiştir. UM HB'nün 13.10.2014 K.T., 2013/1607 E., 2014/887 K. sayılı karar1.

154 “...İdare Mahkemesi ile Sulh Hukuk Mahkemesi kararları arasındaki çelişkinin hüküm uyușmazlı̆̆ı niteliğinde olduğu, tarafların süre sınırı olmaksızın hüküm uyuşmazlığına ilişkin olarak Uyuşmazlık Mahkemesine başvurabilmelerinin mümkün olduğu nitekim benzer konuda Yüksek Mahkemenin olayı bu kapsamda değerlendirerek hüküm uyuşmazlığını giderdiği anlaşılmış; bu yönüyle öngörülen yolun fiilen ve etkin bir şekilde kullanılabildiği sonucuna ulaşılmıştır." Anayasa Mahkemesi İkinci Bölüm, Bireysel Başvuru No: 2013/8173, Karar Tarihi: 14.4.2016.
} 
Bu nedenle de uyuşmazlığın çözümü için yapılacak başvuru olağan kanun yolu olarak kabul edilmelidir.

Anayasa Mahkemesi de bu düşünceye uygun olarak hüküm uyuşmazlığına başvuruyu fiilen ve etkin olarak kullanılan bir başvuru yolu olarak kabul etmiş ve bu yola başvurulmadan kendisine başvuru yapılmasına müsaade etmemiştir. Aslında bu karar, Anayasa Mahkemesi'nin somut ve soyut norm denetimleri sirasinda "görev" konusuyla ilgili verdiği kararlarıyla da uyumludur. Zira bu kararlarında Mahkeme, UM'nin görev alına giren konularda son karar mercii olduğunu ve kararlarının kesin olması nedeniyle ilgili mahkemelerin verilen kararlara uymaları gerektiğini belirtmek suretiyle UM'nin etkili bir çözüm sunduğunu hükme bağlamıştır ${ }^{155}$.

Anayasa Mahkemesi çalışmaya konu kararında da UM'nin etkili bir çözüm ortaya koyduğuna temas ederek, aslında yarg1 ayrılı̆̆ sistemini güçlendirici bir yorumda bulunmuş ve bu sistemin bir neticesi olarak ortaya çıkan hüküm uyuşmazlığının varlığı halinde UM'ne başvurulması gerektiğini belirtmek suretiyle de bu sistemin devamına verdiği önemi göstermiştir.

Varlık sebeplerine bakıldığında bireysel başvuru yolu ile hüküm uyuşmazlığının benzer nitelikte oldukları görülecektir. Zira bireysel başvurunun amacı, kamu gücü kullanılarak hakları ihlâl edilen kişilerin mağduriyetlerinin giderilmesi, hüküm uyuşmazlığının amacı da çelişkili kararlar nedeniyle hakkın yerine getirilmesinin önündeki engellerin

\footnotetext{
155 “...Uyuşmazlık Mahkemesinin verdiği kararlar, niteliği itibariyle görüş bildiren değil, sorunu kesin olarak çözümleyen yargısal tasarruflardır. Bu nedenle, görevli merciin belirlenmesi için Uyuşmazlık Mahkemesine başvuru, 2247 sayılı Yasa'nın 19. maddesine göre yapılmış olsa da sorunun çözümüne ilişkin yüksek Mahkemenin verdiği karara uyması, yukarıda açılanan nedenlerle ilgili mahkeme yönünden anayasal bir zorunluluktur. Konya 1. İdare Mahkemesi ise Uyuşmazlık Mahkemesinin adli yargının görevli olduğu yolundaki kesin olarak verilen kararından sonra itiraz konusu kuralın iptali için Anayasa Mahkemesine başvurmuştur. Oysa anılan Mahkemenin dosya üzerindeki yargısal tasarruf hakkl, Uyuşmazlık Mahkemesinin karar tarihi itibarıla son bulduğundan, Mahkemenin dosyayı görevli mahkemeye göndermesi dışında yetkisinin bulunmadığı açıktır. Bu nedenle başvuran mahkemenin elinde Anayasanın 152. ve 2949 sayıl Yasa'nın 28. maddesi anlamında görevine giren ve bakmakta olduğu bir dava bulunmadı̆̆ından, itiraz başvurusunun başvuran Mahkemenin yetkisizliği nedeniyle reddi gerekir.” Anayasa Mahkemesi'nin 06.3.2008 K.T., 2004/93 E., 2008/73 K. say11 kararı.
} 
kaldırılmasıdır. Bireysel başvuru şartlarından birisi, kanunlarda öngörülmüş idari ve yargısal başvuru yollarının tüketilmesidir. Hüküm uyuşmazlı̆̆ı, verildiği anda kesin olan bir mahkeme kararıyla kişilerin haklarına kavuşmasını sağlayan yoldur ve Anayasa Mahkemesi'nin bireysel başvuruda öncelikle bu yola başvurulması gerektiğine ilişkin kararı da son derece isabetlidir. Aksi durumun kabulü, etkili bir başvuru yolu olan hüküm uyuşmazlığının görmezden gelinerek, Anayasa Mahkemesi'nin kendisini UM'nin yerine koyması anlamına gelir.

Kararla ilgili isabetli olmadığını düşündüğümüz husus ise Anayasa Mahkemesi'nin idare mahkemesi ile sulh hukuk mahkemesi kararı arasındaki çelişkinin "hüküm uyuşmazllğı niteliğinde olduğu” na ilişkin tespitidir. Anayasa Mahkemesi'nin kararında bu kadar kesin ve net bir olguya yer vermemesi ve "hüküm uyuşmazlı̆̆ niteliğinde olabileceğì" şeklinde tespitte bulunup, bu konudaki kararı UM'ne bırakması daha isabetli olurdu. Zira bu karardan sonra UM'ne hüküm uyuşmazlığının çözümü için yapılan başvuruda UM'nin söz konusu mahkeme kararları arasında hüküm uyuşmazlığı bulunmadığına karar vermesi durumunda, Anayasa Mahkemesi'nin "olduğu" na işaret ettiği bir hususla ilgili UM'nin "olmadiğına" ilişkin kararı ayrı bir çelişkiye neden olacak ve yerel mahkeme kararları arasındaki çelişkiden dolayı Anayasa Mahkemesi ve sonrasında UM'ne müracaat eden başvurucu bu kez de iki Yüksek Mahkeme tarafından verilen çelişkili kararlarla karşılaşacaktır.

Ayrıca, Anayasa'nın 153. maddesinin son fikrasındaki Anayasa Mahkemesi kararlarının herkesi bağlayıcı olduğuna ilişkin hükmü karşısında UM Anayasa Mahkemesi'nden farklı olarak hüküm uyuşmazlığı bulunmadığına karar verebilecek midir? Bize göre, Anayasa'nın 153. maddesinin son fikrası hükmünün sadece "olduğu" kelimesi açısından değerlendirilmemesi ve değerlendirmenin kararın sonucu itibariyle yapılması gerekir. Kaldı ki; Anayasa Mahkemesi'nin bu kararında "olduğu" kelimesine yer vermesindeki amacı, kararlar arasında hüküm uyuşmazlığı bulunduğunu tespitten çok, hüküm uyuşmazlığının çözümü için UM'ne başvurunun tüketilmesi gereken bir yol olduğunu belirtmektir. Kararda, UM tarafindan verilmiş başka bir hüküm uyuşmazlığı kararına atıf yapılması da bunun bir göstergesidir ${ }^{156}$.

\footnotetext{
${ }^{156}$ Anayasa Mahkemesi, UM HB'nün 13.10.2014 K.T., 2013/1607 E., 2014/887 K. say11 kararına atıf yapmıştır.
} 
Aynı şekilde daha önce verdiği kararlarında yargı ayrılığı rejiminin varlığına ve önemine değinen, UM'nin de bu sistemin bir neticesi olduğunu belirten Anayasa Mahkemesi'nin ${ }^{157}$, önceki kararlarından ayrılarak UM yerine geçerek karar verdiğini, kararda yer verilen "olduğu” ifadesinin UM'ni bağladığını ve UM'nin bu konuda yapılacak başvuruda hüküm uyuşmazlığ 1 bulunduğuna karar vermek zorunda olduğunu söylemek doğru bir yaklaşım olmayacaktır. Çünkü Anayasa ve yasalarda yüksek mahkemelerde dâhil bütün mahkemelerin görevleri bellidir ve yargı sistemimizde hüküm uyuşmazlıklarını çözme görevi UM'ne verilmiştir. $\mathrm{Bu}$ görevin içine kararlar arasında hüküm uyuşmazlığ bulunup bulunmadığını tespit de girer ve bu tespitin UM dışında başka bir mahkeme tarafindan yapılması mümkün değildir.

Yukarıda yer verilen açıklamalardan hareketle; Anayasa Mahkemesi'nin kararında yer verdiği "olduğu" kelimesiyle amacin aşıldığı söylenebilirse de, kelimenin "olabileceği" şeklinde yorumlanması, UM'nin kararlar arasında hüküm uyuşmazlığı bulunmadığına da karar verebileceği ve verilen karardan tatmin olmayan başvurucunun bireysel başvuru yoluna müracaat edebileceği en isabetli yorum olacaktır. Belirtilen husus dışında verilen karar son derece yerindedir ve kararda başvuru yollarının örnekleriyle gösterilip, başvurucuların öncelikle bu yollara yönlendirilmesi ve mevzuatımızda yer verilen başvuru yollarına işlerlik kazandırılması doğru bir yaklaşımdır.

\section{Sonuc}

Bir ülkede yarg1 ayrıllı̆ı sisteminin geçerli olduğunun en önemli göstergelerinden birisi, diğer mahkemelerden bağımsız olarak faaliyet gösteren bir UM'nin varlığıdır. Ülkemizde de yarg1 ayrılığı sisteminin bir neticesi olarak Fransa ve Cezayir'de olduğu gibi UM diğer mahkemelerden ayrı ve bağımsız bir yüksek mahkeme olarak faaliyet göstermektedir. UM görev alanı itibariyle farklı yargı kolları arasında çıkan görev ve hüküm uyuşmazlıklarını çözmektedir. Görev uyuşmazlıklarını çözmek suretiyle görevli yargı merciini belirleyip,

\footnotetext{
157 “...Anayasa'nın "Uyuşmazlık Mahkemesi” başlıklı 158. maddesinde adlî idarî ve askerî yargı mercileri arasındaki görev ve hüküm uyuşmazlıklarını kesin olarak çözmekle yetkili kılman Uyuşmazlık Mahkemesinin varlı̆g daha önce kabul edilen yargl ayrıllğg sistemini doğrulayan somut örgütlenme biçimleridir. Anayasa Mahkemesi'nin 28.2.1989 K.T., 1988/32 E., 1989/10 K. sayılı kararı.
} 
yargılamanın görevli mahkemede başlamasını sağlamakta, hüküm uyuşmazlığını çözmek suretiyle de kişilerin askıda kalan haklarına kavuşmalarını sağlayarak hukuk devleti ilkesinin varlığını pekiştirmektedir. Mahkeme hüküm uyuşmazlıklarını çözerken diğer hiçbir mahkemeye verilmemiş olağanüstü yetkileri kullanmakta ve şartların varlığı halinde kesinleşmiş yargı kararlarını kaldırıp dosyanın esası hakkında karar verebilmektedir.

Çalışmanın konusunu oluşturan Anayasa Mahkemesi kararında $\mathrm{da}^{158}$, UM'nin uyuşmazlıkları çözerken etkili bir çözüm ortaya koyduğu Anayasa Mahkemesi tarafından tescillenmiş ve hüküm uyuşmazlığ şartlarının bulunduğu durumlarda bireysel başvurunun kabulü için ilk önce ortaya çıkan uyuşmazlığın çözümünün UM'den istenmesi gerektiği hükme bağlanmıştır. Karar, bu yönüyle yargı ayrılığı sistemine verilen önemin bir göstergesidir. Kararla ilgili eleştirilebilecek tek husus, başvuruya konu mahkeme kararları arasındaki çelişkinin hüküm uyuşmazlığı "olduğu” na ilişkin kesin hüküm içeren ifadesidir. Ancak kararda yer verilen ifadeyle başvurunun öncelikle UM'ne yapılması hususunda yol gösterildiği ve hüküm uyuşmazlığının varlığı konusunda UM'ni bağlayıcı bir yönünün bulunmadığı düşünülmektedir. Belirtilen husus dışında verilen karar, AHİM'nin kararlar arasındaki içtihat uyumunu sağlayacak mekanizmaların oluşturulmasına ilişkin önerisinin en somut örneği olan UM'nin, yarg1 sistemindeki varlığını pekiştiren ve UM'ne yapılacak başvuruların, Anayasa Mahkemesi açısından etkin ve sonuç almaya yönelik olduğunu gösteren isabetli bir karardır.

\section{Kaynakça}

ANIL, Ayten, “Uyuşmazlık Mahkemesi’nin Kuruluşu ve İşleyiş̧”, Ankara Üniversitesi Siyasal Bilgiler Fakültesi Dergisi, S. 47/1-2, Ankara, 1992, (Sayfa 45-50).

ATASOY, Hakan, Anayasa Mahkemesine Bireysel Başvuruda Kabul Edilebilirlik Koşulları, Adalet Yayınevi, Ankara, 2015.

158 Anayasa Mahkemesi İkinci Bölüm, Bireysel Başvuru No: 2013/8173, Karar Tarihi: 14.4.2016. 
BARUTOĞLU, Tulez, "Uyuşmazlık Mahkemesine Başvuru Yolları", Adalet Dergisi, S. 3, Ankara, 1986, (Sayfa 119-167).

ÇAĞLAYAN, Ramazan, İdari Yargılama Hukuku, 4. Baskı, Seçkin Yayinevi, Ankara, 2014, ("Yargllama").

DİNÇ, M. İlhan, "Hüküm Uyuşmazlıkları ve Çözümü”, Danıştay Dergisi, S. 70-71, Ankara, 1988, (Sayfa 5-32).

DURAN, Lütfi， Uyuşmazlık Mahkemesi İçtihatlarına Göre Vazife ve Hüküm İhtilafları, (Yayımlanmamış Doçentlik Tezi), İstanbul, 1950.

DUYSAK FIDAN, Seda, Anayasa Yargısında Bireysel Başvuru Yolu ve Türkiye'de Gelişimi, Yayımlanmamış Yüksek Lisans Tezi, Ankara, 2013.

EFE, Metin, Anayasa Mahkemesi Uygulamaları Kapsamında Bireysel Başvuruda Kabul Edilebilirlik Şartları, Seçkin Yayıncılık, Ankara, 2016.

EKİNCI, Hüseyin/SAĞLAM, Musa, Sorularla Anayasa Mahkemesi’ne Bireysel Başvuru, Anayasa Mahkemesi Yayınları, Ankara, 2014.

EKİNCI, Hüseyin "Kabul Edilebilirlik Kriterleri”, Bireysel Başvuru, İnceleme Usulü ve Kabul Edilebilirlik Kriterleri, (Editör: Musa SAĞLAM), Şen Matbaa, Ankara, 2013, ("Kriterler"), (Sayfa 109-161).

EKINCI, Hüseyin, "Anayasa Mahkemesine Bireysel Başvurularda Bir Kabul Edilebilirlik Koşulu Olarak "Başvuru Yollarının Tüketilmesi" Sorunu", Türkiye Adalet Akademisi Dergisi, Y: 3, S. 11, Ankara, 2012, (Sayfa 1-21).

ER, Selami, "Bireysel Başvuru İncelemesinde Mülkiyet Hakkı", İnsan Onuru İçin Anayasa Mahkemesinde 25 Yıl, Haşim KILIÇ’a Armağan, (Editörler: Ali Rıza ÇOBAN/Serdar GÜLENER/Musa SAĞLAM/Hüseyin EKİNCI), C. 2, Ankara, 2015, (Sayfa 1427-1485).

GÖZÜBÜYÜK, A. Şeref/TAN, Turgut, İdare Hukuku-İdari Yargılama Hukuku, C. 2, 5. Bası, Turhan Kitapevi, Ankara, 2012. 
GÖZTEPE, Ece, “Türkiye'de Anayasa Mahkemesi'ne Bireysel Başvuru Hakkının (Anayasa Şikâyeti) 6216 Sayılı Kanun Kapsamında Değerlendirilmesi”, Türkiye Barolar Birliği Dergisi, S. 95, Ankara, 2011, (Sayfa 13-40).

Kabul Edilebilirlik Kriterleri, (Editör: Musa SAĞLAM/Hasan Tuna GÖKSU), Anayasa Mahkemesi Yayınları, Ankara, 2014.

KURU, Baki, Hukuk Muhakemeleri Usulü, Demir Demir Yayınc1lik, C. 1, İstanbul, 2001.

ONAR, Sıddık Sami, İdare Hukukunun Umumi Esasları, C. 1, 3. Bası, İsmail Akgün Matbaası, İstanbul, 1966.

ÖZBEY, Özcan, Türk Hukukunda Anayasa Mahkemesine Bireysel Başvuru Hakkı, Adalet Yayınevi, Genişletilmiş 2. Bask1, Ankara, 2013, (“Bireysel Başvuru”).

ÖZBEY, Özcan, “Anayasa Mahkemesine Bireysel Başvurularda Kabul Edilmezlik Nedenleri”, Türkiye'de Anayasa Mahkemesine Bireysel Başvuru (Anayasa Şikâyeti), (Editör: Sevtap YOKUŞ), Seçkin Yayınc1lik, Ocak 2014, Ankara, ("Anayasa Şikayeti"), (Sayfa 185-227).

RESULOĞLU, Mustafa, Uyuşmazlık Mahkemesi ve Görev ile Hüküm Uyuşmazlıkları, TODAİE, Yayımlanmamış Uzmanlık Tezi, Ankara, 1988.

SAĞLAM, Musa/EKİNCİ, Hüseyin, 66 Soruda Anayasa Mahkemesine Bireysel Başvuru, Şen Matbaası, Ankara, 2012.

ŞEN, Murat, "Başvuru Yollarının Tüketilmesi Kuralı", Anayasa Mahkemesine Bireysel Başvuru Usulü ve Kabul Edilebilirlik Kriterleri, (Editörler: Hüseyin TURAN/Recep KAPLAN), Anayasa Mahkemesi Yayınları, Ankara, 2015, (Sayfa 85-146).

TERCAN, Erdal, "Hüküm Uyuşmazlığında Uyuşmazlık Mahkemesince Esas Hakkında Yeni Bir Karar Verilmesi”, Uyuşmazlık Mahkemesi Dergisi 70. Yıl Armağanı, S. 5, Ankara, 2015, ("Esas Hakkında"), (Sayfa 783-825).

TERCAN, Erdal, Farklı Yargı Kollarına Mensup Mahkemeler Arasındaki Hüküm Uyuşmazlığı, Uyuşmazlık Mahkemesi Yayınları, Ankara, 2014. 
TÜRMEN, Rıza, "İnsan Hakları Sözleşmesi Sisteminde İç Hukuk Yollarının Tüketilmesi”, İstanbul Üniversitesi Hukuk Fakültesi Dergisi, Prof. Dr. Sahir ERMAN'a Armağan, No: 8, İstanbul, 1999, (Sayfa 775-792).

ÜNAL, Recep, Bireysel Başvuru Çerçevesinde İfade Özgürlüğü, Yayımlanmamış Doktora Tezi, Kırıkkale, 2014.

YENISEY, Feridun/NUHOĞLU, Ayşe, Ceza Muhakemesi Hukuku Ders Kitabı, Bahçeşehir Üniversitesi Yayınları, İstanbul, 2014.

YEŞiL, Ufuk, Türk Yargı Sisteminde Görev ve Hüküm Uyuşmazlıklarının Çözüm Usulü, Uyuşmazlık Mahkemesi Yayınları, Ankara, 2016.

YİĞìT, Birgül, "Oluşumu, Görev Alanı ve Başvuru Yolları ile Uyuşmazlık Mahkemesi'nin Temel Yapısına Genel Bir Bakış", Uyuşmazlık Mahkemesinin Kuruluşunun 70. Yılı Uluslararası Sempozyumu, (Editör: Ufuk YEŞiL), Uyuşmazlık Mahkemesi Yayınları, Ankara, 2015, (Sayfa 197-238). 
Ufuk YEŞiL 